\title{
Cerro Porã Batholith: post-orogenic A-type granite from the Amoguijá Magmatic Arc - Rio Apa Terrane - South of the Amazonian Craton
}

\author{
Batólito Cerro Porã: granito tipo-A pós-orogênico do arco \\ magmático Amoguijá - terreno Rio Apa - sul do Cráton Amazônico
}
Dalila PexePlens ${ }^{1,2,3 *}$, Amarildo Salina Ruiz ${ }^{1,2,3,4}$, Maria Zélia Aguiar de Sousa ${ }^{1,2,3,5}$, Maria Elisa Fróes Batata ${ }^{2}$, Jean-Michel Lafon ${ }^{3,6}$, Ana Flávia Nunes Brittes ${ }^{1,2,3}$

\begin{abstract}
The Cerro Porã Batholith has an approximately area of $30 \mathrm{~km}$ by $4 \mathrm{~km}$, situated at the region of Porto Murtinho, Mato Grosso do Sul. It is located in Rio Apa Terrane, at the southern portion of the Amazonian Craton. It consists of Pink Syenogranitic Facies and Gray Monzogranitic Facies. The first facies is characterized by xenomorphic equigranular texture to essentially inequigranular texture with graphic and granophiric intergrowths. Both facies are composed of alkali feldspar, quartz, and plagioclase with biotite as the only primary mafic mineral. The Gray Monzogranitic Facies has porphyritic texture with graphic to granophiric fine-grained groundmass. It consists of quartz, plagioclase, alkali feldspar, and mafic aggregates (biotite and amphibole). Both facies were metamorphosed at greenschist facies and the Pink Syenogranitic Facies, which is milonytic in nature when it is in shear zones. One event of ductile-brittle deformation was identified, originated in a compressive system. It was responsible for the schistosity and mineral-stretching lineation. The development of the Esperança shear zone is related to this deformational phase and reflects the cinematic history of the reverse convergent system with top transport to NWW. Chemically, these rock types are classified as A2-type granitoids of range alkaline potassium saturated on silica. Geochronological data obtained by U-Pb (Sensitive High Resolution Ion Microprobe) method in zircon resulted in an age of $1749 \pm 45 \mathrm{Ma}$, interpreted as crystallization age of the batholith. From the geotectonic point, the Cerro Porã Granite is considered to be the product of a magmatism associated with a magmatic arc developed in Statherian and emplaced in late-orogenic to post-orogenic stage.
\end{abstract}

KEYWORDS: Cerro Porã Granite; A-type Granite; geochemistry; geochronology U-Pb.
RESUMO: O Batólito Cerro Porá é um corpo de aproximadamente 30 por $4 \mathrm{~km}$ de extensão, localizado na regiäo de Porto Murtinho, Mato Grosso do Sul. Situa-se nos domínios do Terreno Rio Apa, porção sul do Cráton Amazônico. Constitui-se pela Fácies sienogranítica rosa e Fácies monzogranitica cinza. A primeira é caracterizada por textura equi a, essencialmente, inequigranular xenomórfica e pela presença constante de intercrescimentos gráfico e granofíric; constitui-se por feldspatos alcalinos, quartzo e plagioclásio, tendo biotita como único máfico primário. A Fácies monzogranitica cinza apresenta textura porfiritica, com uma matriz de granulação fina gráfica a granofírica e consiste de quartzo, plagioclásio, feldspatos alcalinos e agregados máficos (biotita e anfibólio). Ambas foram metamorfizadas na fácies xisto verde e a Fácies sienogranitica rosa mostra-se milonitizada quando em zonas de cisalhamento. Foi identificado um evento deformacional dúctil-rúptil originado em regime compressivo, responsável pela geração de xistosidade e lineação de estiramento mineral. A Zona de Cisalhamento Esperança relaciona-se a esta fase e reflete a história cinemática convergente, reversa a de cavalgamento, com transporte de topo para NWW. Quimicamente, esses litotipos classificam-se como granitoides do tipo A2 da série alcalina potássica saturada em sílica. Determinação geocronológica obtida pelo método U-Pb (SHRIMP) em zircão, forneceu idade de $1749 \pm 45 \mathrm{Ma}$ para sua cristalização. Do ponto vista geotectônico, admite-se que o Granito Cerro Porã corresponda a um magmatismo associado a um arco vulcânico desenvolvido no Estateriano e que sua colocaçáo se deu no estágio tardi a pós-orogênico.

PALAVRAS CHAVES: Granito Cerro Porä; Granito tipo A; geoquímica; geocronologia U-Pb.

${ }^{1}$ Graduate Program in Geosciences, Instituto de Ciências Exatas e da Terra, Universidade Federal de Mato Grosso - UFMT, Cuiabá (MT), Brazil. E-mail: dalilaplens@gmail.com

${ }^{2}$ Research Group in Crustal Evolution and Tectonics - Guaporé, Mineral Resources Department, Instituto de Ciências Exatas e da Terra, Universidade Federal de Mato Grosso - UFMT, Cuiabá (MT), Brazil. E-mail: elisabatata@hotmail.com

${ }^{3}$ National Institute of Sciences and Geoscience Technology of theAmazon (Instituto Nacional de Ciência e Tecnologia de Geociências da Amazônia - GEOCIAM). ${ }^{4}$ General Geology Department, Instituto de Ciências Exatas e da Terra, Universidade Federal de Mato Grosso - UFMT, Cuiabá (MT), Brazil. E-mail: asruiz@gmail.com; ${ }^{5}$ Mineral Resources Department, Instituto de Ciências Exatas e da Terra, Universidade Federal de Mato Grosso - UFMT, Cuiabá (MT), Brazil. E-mail: prof. mzaguiar@gmail.com

${ }^{6}$ Isotope GeologyLaboratory (Pará-Iso), Geosciences Institute of Universidade Federal do Pará - UFPA, Belém (PA), Brazil. E-mail:lafonjm@ufpa.br

*Corresponding author

Manuscrito ID: 29902. Recebido em: 30/01/2013. Aceito em: 15/08/2013. 


\section{INTRODUCTION}

The pioneering studies by Hussak (1894 apud Lisboa 1909) revealed the existence of an acidic voluminous magmatism in the present SW region of MatoGrosso do Sul. Correia Filho et al. (1981), Araújo et al. (1982), and Godoi et al. (2001) grouped these intrusions within the Alumiador Intrusive Suite. Lacerda Filho et al. (2006) positioned them as part of the Amoguijá Magmatic Arc with U-Pb in zircon (Sensitive High Resolution Ion Microprobe, SHRIMP) aged around $1867 \mathrm{Ma}$. Cordani et al. (2010) established ages of $1839 \pm 33 \mathrm{Ma}$, which were obtained by using the same method for these rocks.

The purpose of this study is to contribute to the understanding of the magmatic history of the Alumiador Intrusive Suite and, as a consequence, the Amoguijá Magmatic Arc, through geological and petrographic characterization of the Cerro Porã Granite (CPG). Geochemical and geochronological analyses (U-Pb/SHRIMP in zircon) were employed to define the age of the intrusion, the petrogenesis of the magma, and the probable tectonic environment in which it was generated.

\section{REGIONAL TECTONIC CONTEXT}

The Amazonian Craton constitutes the largest Precambrian geotectonic entity of South America and is divided by the Amazonas Syneclise into two shields: Central Brazil and the Guianas shields. Since the study of Cordani et al. (1979), the evolution of this craton has been interpreted as a succession of magmatic arcs that added to the margin of an Archean core, the Central Amazonian Province. According to the studies (Cordani \& Brito Neves 1982; Teixeira et al. 1989; Tassinari 1996; Tassinari \& Macambira 1999; Cordani \& Teixeira 2007; Santos et al. 2000, 2008; Ruiz 2005; Bettencourt et al. 2010; Cordani et al. 2010), accretion of juvenile crust and crustal reworking acted on successive orogenic and traphogenic events from the Paleozoic to the Neoproterozoic. Recovering the idea by Almeida (1967) and Amaral (1974), Ruiz (2005), and Cordani et al. (2010) positioned the Rio Apa Terrane as part of the Amazonian Craton (Fig. 1), based on geological and geochronological considerations; and this proposal was adopted in this study.

Lacerda Filho et al. (2006) subdivided the Rio Apa Terrane into three distinct geotectonic compartments as follows: (a) a remnant of oceanic crust, with Rhyacian age, represented by the Alto Tereré Metamorphic Complex; (b) the Orosian Rio Apa Magmatic Arc, represented by Gneisses of the Rio Apa Complex; and (c) the Statherian
Amoguijá Magmatic Arc, consisting of the Serra da Bocaina Formation and the granitoids of the Alumiador Intrusive Suite. Mafic bodies in the form of batholiths and dykes are grouped as part of the Continental Mafic Magmatism, most likely from the Statherian or Tonian periods.

The initial descriptions referring to the rocks of the Alumiador Granite were made by Hussak (1894 apud Lisboa 1909) and Oliveira and Moura (1944). Corrêa et al. (1976) used the term Basal Complex to refer to the acid intrusive granitic and microgranitic rocks from the Lower to Middle Pre-Cambrian. Schobbenhaus and Soares (1979) described massifs composed of granites, graphic granites, porphyritic biotite microgranites, aplites, granitic gneisses, and acidic volcanics, which were grouped under the name of the Amoguijá Complex. Nogueira et al. (1978) called the three granitic bodies along the eastern border of the Serra da Bodoquena the acid intrusives.

Correia Filho et al. (1981) adopted the name Amoguijá Group to designate the rocks from the complex with the same name, and later, Araújo et al. (1982) used the term Alumiador Intrusive Suite to designate the granitoids that support the hills of the Alumiador, exposed as granitic, granodioritic, and (less commonly) sub-volcanic bodies consisting of various granophyres, including the porphyritic and microgranular types.

Godoi et al. (1999) restricted the term Alumiador Intrusive Suite to describe microgranites, granophyres, granites, granodiorites, and monzogranites, whereas Godoy et al. $(2007,2009)$ used the term Alumiador Batholith to describe the isotropic to weakly anisotropic, leucocratic, with color gray, and predominantly pink rocks.

The U-Pb data (SHRIMP) shown by Lacerda Filho et al. (2006) and Cordani et al. (2010) indicate values of $1867 \mathrm{Ma}$ and $1839 \pm 33 \mathrm{Ma}$, respectively, for the rocks from the Alumiador Granite. The latter authors reported $\mathrm{Rb}-\mathrm{Sr}$ reference isochron for these rocks varying from 1630 to $1740 \mathrm{Ma}$, with an initial isotropic ratio of 0.705 .

Lacerda Filho et al. (2006) present Sm-Nd (whole rock) results with a model age $\left(\mathrm{T}_{\mathrm{DM}}\right)$ of $2.17 \mathrm{Ga}$ for the Alumiador Granite and slightly negative $\varepsilon_{\mathrm{Nd}(\mathrm{T})}$ values of -0.68.

Ar-Ar and K-Ar results for the granitic rocks vary between 1300 and $1315 \mathrm{Ma}$ (Araújo et al. 1982; Cordani et al. 2010). Table 1 summarizes the geochronological data from the Alumiador Intrusive Suite available in the literature.

\section{FIELD AND PETROGRAPHIC ASPECTS OF THE CERRO PORÃ GRANITE}

The CPG, individualized in this study, is a batholith stretching approximately $120 \mathrm{~km}^{2}$ along the NNE direction. The southern portion of the intrusion has NS 
Table 1. Analyses performed on the granitic rocks of the Alumiador Intrusive Suite using the U-Pb (SHRIMP) on zircons, $\mathrm{K}-\mathrm{Ar}, \mathrm{Ar}-\mathrm{Ar}, \mathrm{Rb}-\mathrm{Sr}$, and Sm-Nd methods

\begin{tabular}{l|c|c|c|c|}
\hline \multicolumn{3}{|c|}{ AGES } \\
\hline \multirow{2}{*}{ U-Pb SHRIMP Ga } & K-Ar Ma & \multicolumn{2}{|c|}{ Ar-Ar (biotita) Ma } & \multirow{2}{*}{ Rb-Sr Ma } \\
\cline { 3 - 5 } & & Plateau Age & Integrated Age & TDM Ga \\
\cline { 3 - 5 } $1867^{* *}$ & $1314 \pm 19^{*}$ & $1302 \pm 3^{*}$ & $1296 \pm 2^{*}$ & $2,40^{*}$ a $1740^{*}$ \\
\hline $1839 \pm 33^{*}$ & & & $1600 \pm 40^{* * *}$ \\
\hline
\end{tabular}

References: *Cordani et al. (2010); **Lacerda Filho et al. (2006); ***Araújo et al. (1982).

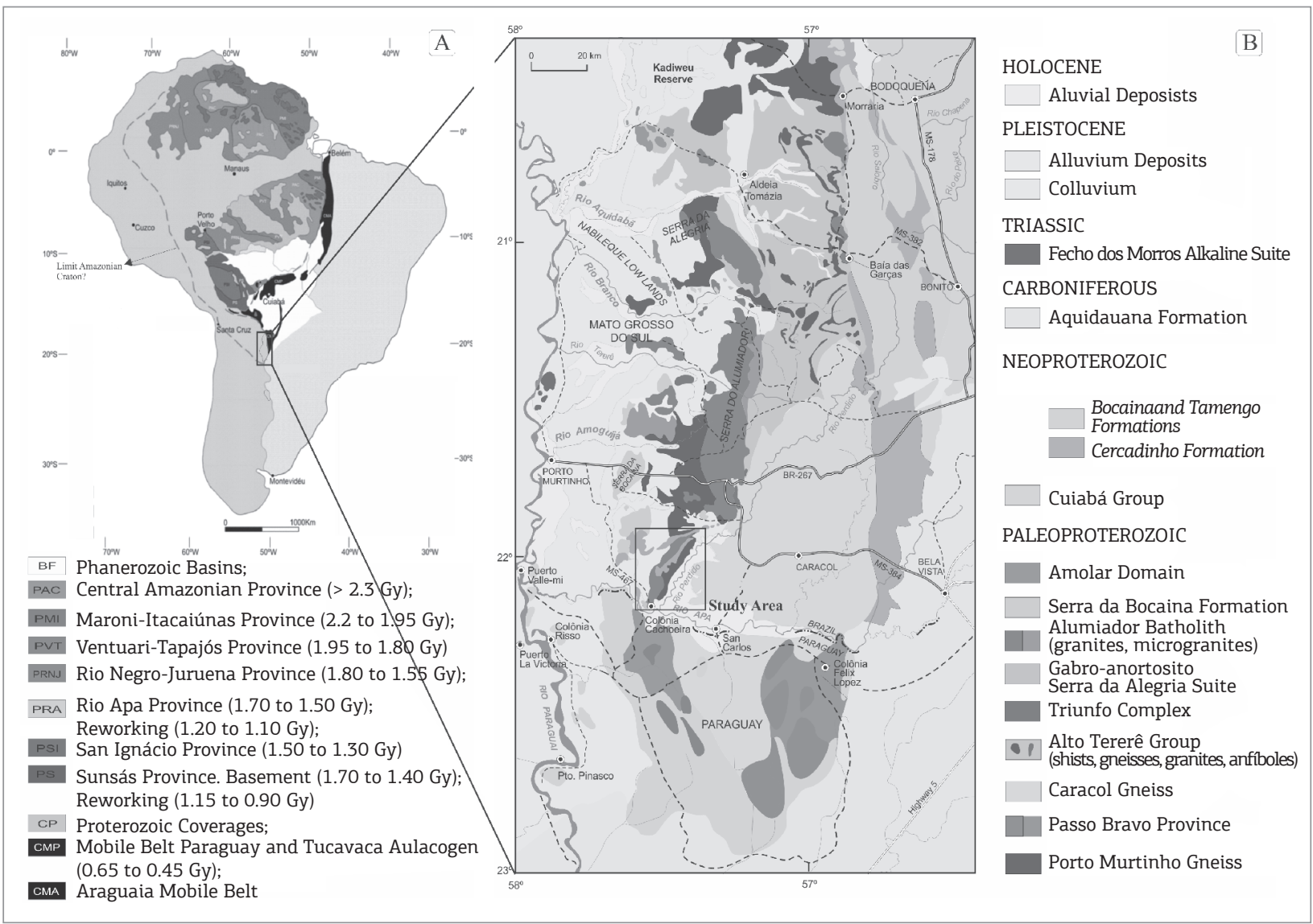

Figure 1. (A) Compartmentation of the Amazonian Craton (after Ruiz 2005), highlighting the Rio Apa Terrane; (B) Geological outline of the Rio Apa Terrane (after Cordani et al. 2010).

direction, whereas the north portion is oriented following $\mathrm{N} 30^{\circ} \mathrm{E}$, conferring a curvilinear form to the Serra da Esperança mountain range. The intrusion maintains tectonic contacts with the Amolar Group and the Serra da Bocaina Formation and is largely covered by sediments from the Pantanal Formation (Fig. 2).

On the basis of field and petrographic characteristics, rocks from the CPG were grouped into two petrographic facies: (a) Pink Syenogranitic Facies (PSF) and (b) Gray Monzogranitic Facies (GMF).

The PSF constitutes approximately $95 \%$ of the intrusion, occurs in the form of blocks and flagstones, and defines the landscape of the Serra da Esperança (Figs. 3A and $\mathrm{B})$. The PSF is formed by pink rocks with equigranular to essentially inequigranular texture medium to fine inequigranular, phaneritic, slightly foliated to massifs, having biotite as the only essential mafic, sometimes, at a percentage that does not reach 5\%, characterizing some samples as hololeucocratic (Fig. 3C). The GMF is observed only in the southern portion of the batholiths. Outcrops in blocks and flagstones, making abrupt contact with the PSF. The GMF consists of the dark gray lithotypes that have a medium to fine or even porphyritic inequigranular texture, locally rapakivi (Fig. 3D), isotropic to slightly 


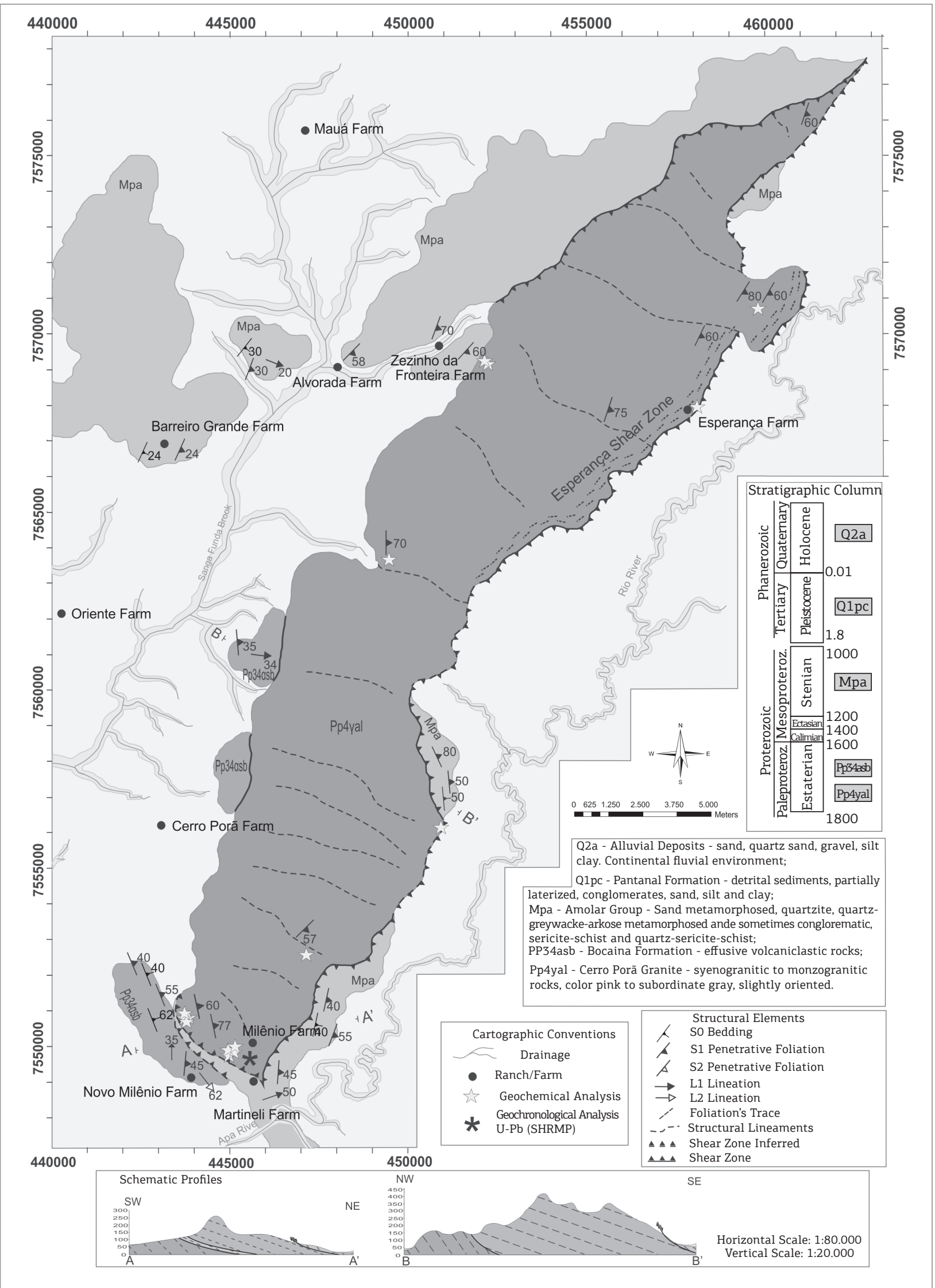

Figure 2. Geological map of the region of the Serra da Esperança, highlighting the Cerro Porã Granite and adjacent units. Location of the samples for geochemical and geochronological analysis. 


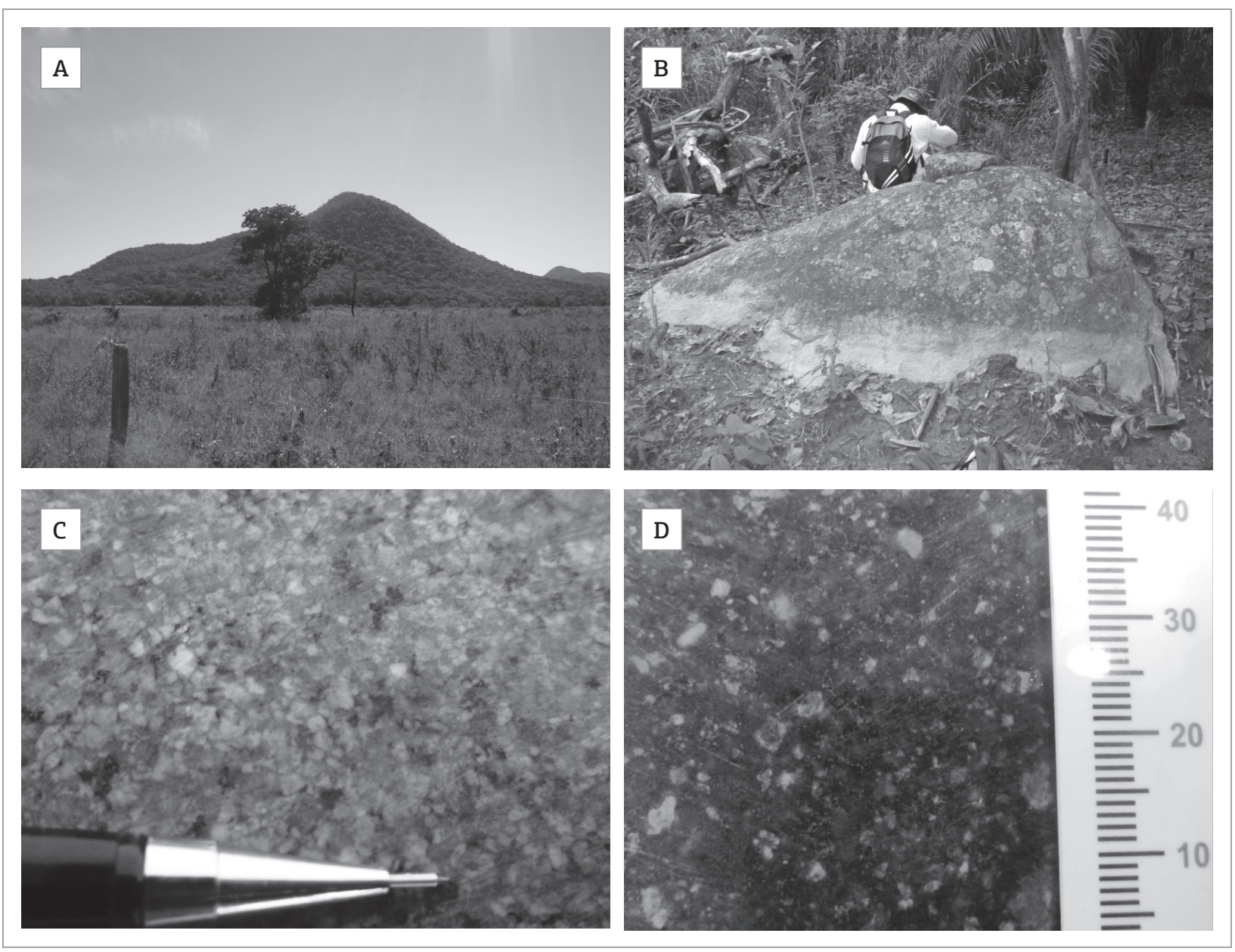

Figure 3. Photographs of the Cerro Porã Granite, illustrating the following: (A) the geomorphological aspect of the Serra da Esperança; (B) form of occurrence in blocks; (C) the macroscopic aspect of Pink Syenogranitic Facies; (D) the macroscopic aspect of Gray Monzogranitic Facies with porphyritic texture, locally rapakivi.

oriented, leucocratic, where phenocrysts of quartz, plagioclase, alkali feldspar, and mafic aggregates are emphasized (biotite, amphibole, and opaque).

Optically, PSF rocks exhibit a xenomorphic inequigranular to equigranular texture and are characterized by the constant presence of graphic and granophyric intergrowths, besides the low quantity of mafics, sometimes less than 5\%. PSF rocks consist essentially of alkali feldspars, quartz, and plagioclase with biotite as the only essential primary mafic phase. The primary accessory paragenesis consists of titanite, allanite, apatite, zircon, and opaques, whereas the products of hydrothermal alteration associated with the stages of low-grade metamorphism of green schist facies are represented by chlorite, sericite, epidote, calcite, clay-minerals, fluorite, rutile, and opaques. PSF rocks may exhibit fractures filled by chlorite and other alteration minerals. When in shear zones, these rocks are classified as mylonites based on the criteria of Sibson (1977), displaying a typical texture with the predominance of matrix.
Microscopically, the GMF displays a porphyritic texture with a matrix of graphic to granophyric fine granulation in which larger crystals of intensely altered plagioclase are highlighted, with alkali feldspars and quartz. GMF rocks consist of a primary paragenesis formed by quartz, plagioclase, alkaline feldspars, and mafic aggregates (amphibole, biotite, and opaques) with apatite, titanite, and opaques as accessory minerals and sericite, muscovite, clay-minerals, epidote/clinozoisite, calcite, and opaques as products of alteration. In contrast with PSF, the mafic minerals always occur in aggregates and account for approximately $30 \%$ of the modal composition of these rocks.

The alkali feldspars occur as embayed phenocrysts with corrosion gulfs or in inter-grown grains with quartz, forming a graphic to fine granophyric matrix (Fig. 4A). They are perthitic and correspond predominantly to microcline with grid twinning (Fig. 4B) and to the orthoclase with Carlsbad twinning (Fig. 4C). Alkali feldspars occur in subhedral crystals of tabular habit to anhedral grains, with variable dimensions, and are generally turbid due to the 

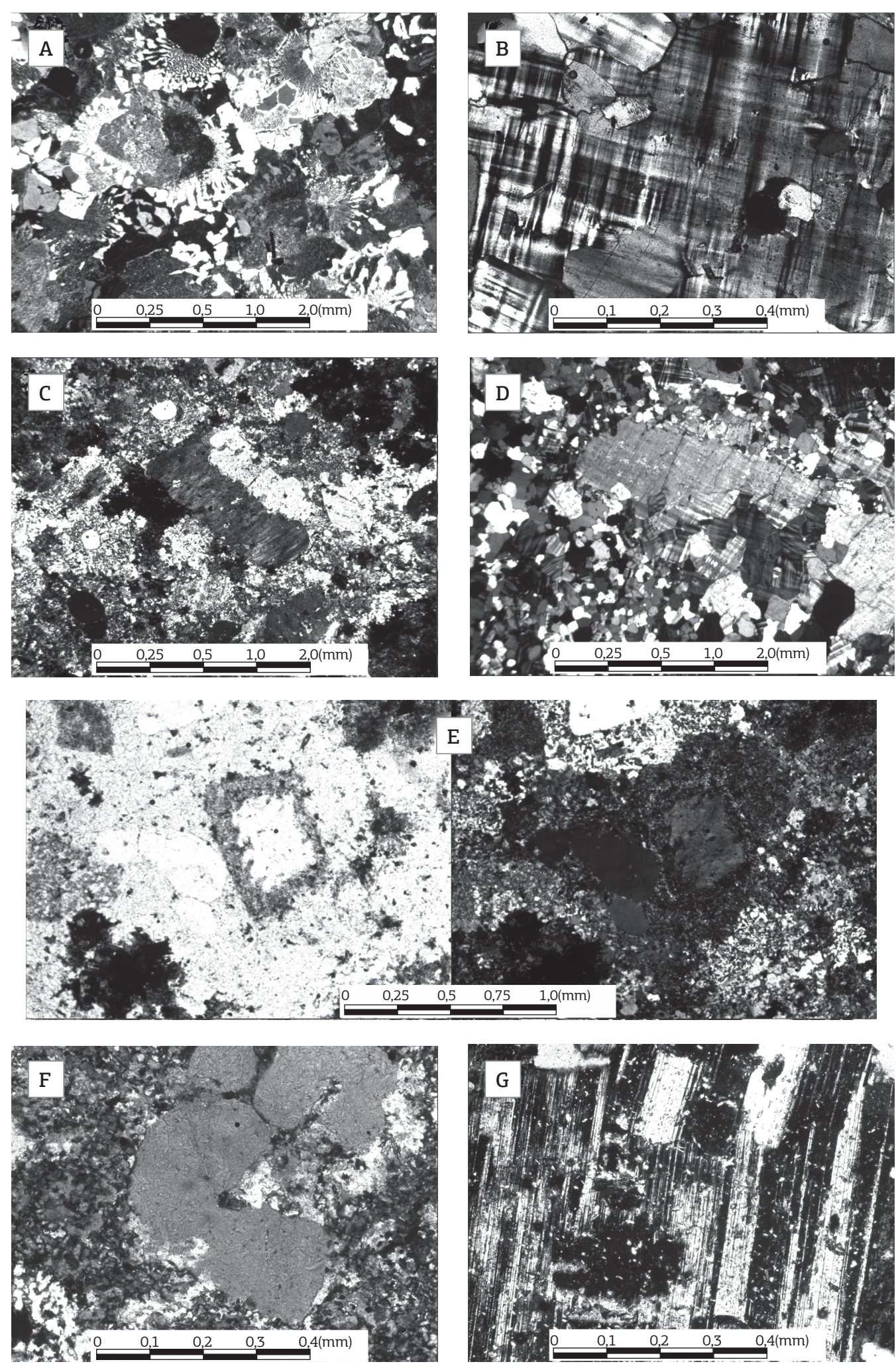

Figure 4. Photomicrographs of the rocks from the Cerro Porã Granite illustrating the following: (A) graphic and granophyric intergrowths in xenomorphic texture in the Pink Syenogranitic Facies; (B) crystal from the perthitic microcline with grid twinning, with an exsolved phase in grains of the Pink Syenogranitic Facies; (C) alkali feldspar phenocryst in a fine inequigranular matrix in the Gray Monzogranitic Facies; (D) grano-lepidoblastic texture where the crystals from the microcline of two generations in the shear zone are highlighted; (E) rapakivi texture with a core of alkali feldspar with a fine halo of saussuritized plagioclase in the Gray Monzogranitic Facies; (F) clear phenocryst of embayed quartz and with corrosion gulfs filled by the matrix in the Gray Monzogranitic Facies; and $(G)$ crossed polarizers in A, B, C, D, and F; parallel to the left and crossed to the right in E. 
alteration to clay minerals and sericite, which sometimes display comminuted edges. Principallu in the lithotypes in the shear zone, beyond the porphyroclasts, they constitute a phase of the matrix representing a second generation of microcline, in smaller unaltered grains (Fig. 4D). Locally, in the GMF rocks, the rapakivi-type texture may be observed, in which the alkaline feldspar core is surrounded by a fine layer of intensely saussuritized plagioclase (Fig. 4E).

Quartz is found in interstitial subhedral crystals and anhedral grains. It also has a graphic to granophyric intergrowth with a microcline exhibiting vermicular, cuneiform, or lobed habits, mainly on the edges of the alkali feldspars; sometimes, the vermiculae are connected to the interstitial quartz, representing the last crystallized phase. In the GMF, quartz also consists of clear phenocrysts commonly embayed and with gulfs caused by the magmatic corrosion processes (Fig. 4F). In the mylonitized lithotypes, quartz occurs in recrystallized grains on the edges of the porphyroclasts and in polygonal crystals forming a mosaic texture. The intracrystalline deformation of quartz is marked by undulating extinction, lamellae, and bands of deformation, as well as by the presence of subgrains.

Plagioclase from both facies corresponds to albite and to oligoclase and occurs in subhedral to anhedral phenocrysts or in small crystals of the matrix, with albite and/or pericline and/or Carlsbad twinning, sometimes displaying a bending of its lamellae, which suggests ductile deformation (Fig. 4G). It is also a host phase for perthitic intergrowth, arranged in strands, films, or grains. It is also found with a myrmekitic texture and can be turbid, displaying advanced post-magmatic stages, such as saussurization and argilization. In the GMF, tabular, subhedral, intensely argilized, and/or saussuritized phenocrysts are exhibited, in which polysynthetic twinning is identified only in a reliquary manner.

Biotite represents the only primary essential mafic phase of the PSF rocks and occurs in anhedral to subhedral veins and plates, with light brown to brown pleochroism, partially to totally substituted by chlorite or muscovite and sometimes deformed into a kink-band. In the deformed lithotypes, biotite occurs in veins arranged according to mylonitic foliation. In the GMF, biotite consists of aggregates of veins of yellow-brown to light-brown pleochroism, which are randomly arranged and are associated with the amphibole, epidote, titanite, and opaques. It sometimes includes euhedral to subhedral crystals of zircon that develop pleochroic halos.

Amphibole is found only in the GMF, comprising mafic aggregates, in grains of blue-green to dark-green pleochroism almost totally pseudomorphized to a set of fine veins of biotite and, mainly, opaques that fill their traces of cleavages.
Allanite occurs as a primary accessory mineral in minuscule metamictic grains with a yellow color associated with epidote. Other minerals of the group of epidote, in addition to allanite, are found as products of saussuritization, generally in miniscule grains of plagioclase, amphibole, and biotite. Apatite represents a primary accessory phase and has an acicular habit that is indiscriminately enclosed in feldspars and biotite. Titanite is also primary and occurs in subhedral crystals that constitute up to $2 \%$ of the modal composition of some lithotypes. Zircon appears as small euhedral to subhedral bipyramidal crystals or in minuscule grains that are dispersed in the matrix or enclosed in biotite.

Fluorite occurs as a product of metasomatism, in miniscule crystals that commonly have its characteristic purple coloration. Rutile is found in miniscule fibrous or acicular crystals that are associated with titanite and with an opaque, possibly ilmenite. Opaque minerals are recognized as primary phases in euhedral crystals or alterations in anhedral grains, sometimes being dendritic or skeletal, with black or brown and red tones, and occur isolated in the matrix or in mafic aggregates.

\section{STRUCTURAL CHARACTERIZATION OF THE CERRO PORÃ GRANITE}

To facilitate the organization and presentation of the data, the following abbreviations were adopted: (Fn) to designate the ductile deformation phase, $(\mathrm{Sn})$ for foliation, $(\mathrm{Ln})$ for lineation, and $(\mathrm{Mn})$ for the metamorphic episode; the letter $n$ represents the deformation phase to which it is related and, when accompanied by the letter $\mathrm{m}$, refers to mylonitic rock.

The data obtained indicate that the CPG shows deformational records compatible with the action of a ductile deformation phase $\left(\mathrm{F}_{1}\right)$ characterized by tenuous, penetrative foliation $\left(S_{1}\right)$ and by the Esperança Shear Zone, when the $S_{1 \mathrm{~m}}$ mylonitic foliation and $\mathrm{L}_{1 \mathrm{~m}}$ stretching lineation are highlighted. A shallow deformation event with a brittle character is also observed, evidenced by the expressive number of fractures that section the intrusion orthogonally.

The first deformation phase $\left(\mathrm{F}_{1}\right)$ is characterized by the development of penetrative foliation $S_{1}$, represented by tenuous preferential orientation of the felsic minerals and of the biotite aggregates (Fig. 5A). Optically, the $S_{1}$ penetrative foliation displays little orientation of the constituent minerals (Fig. 5B). The grains of alkali feldspar exhibit a tabular to prismatic habit with incipient orientation. The quartz occurs in subhedral to anhedral grains 


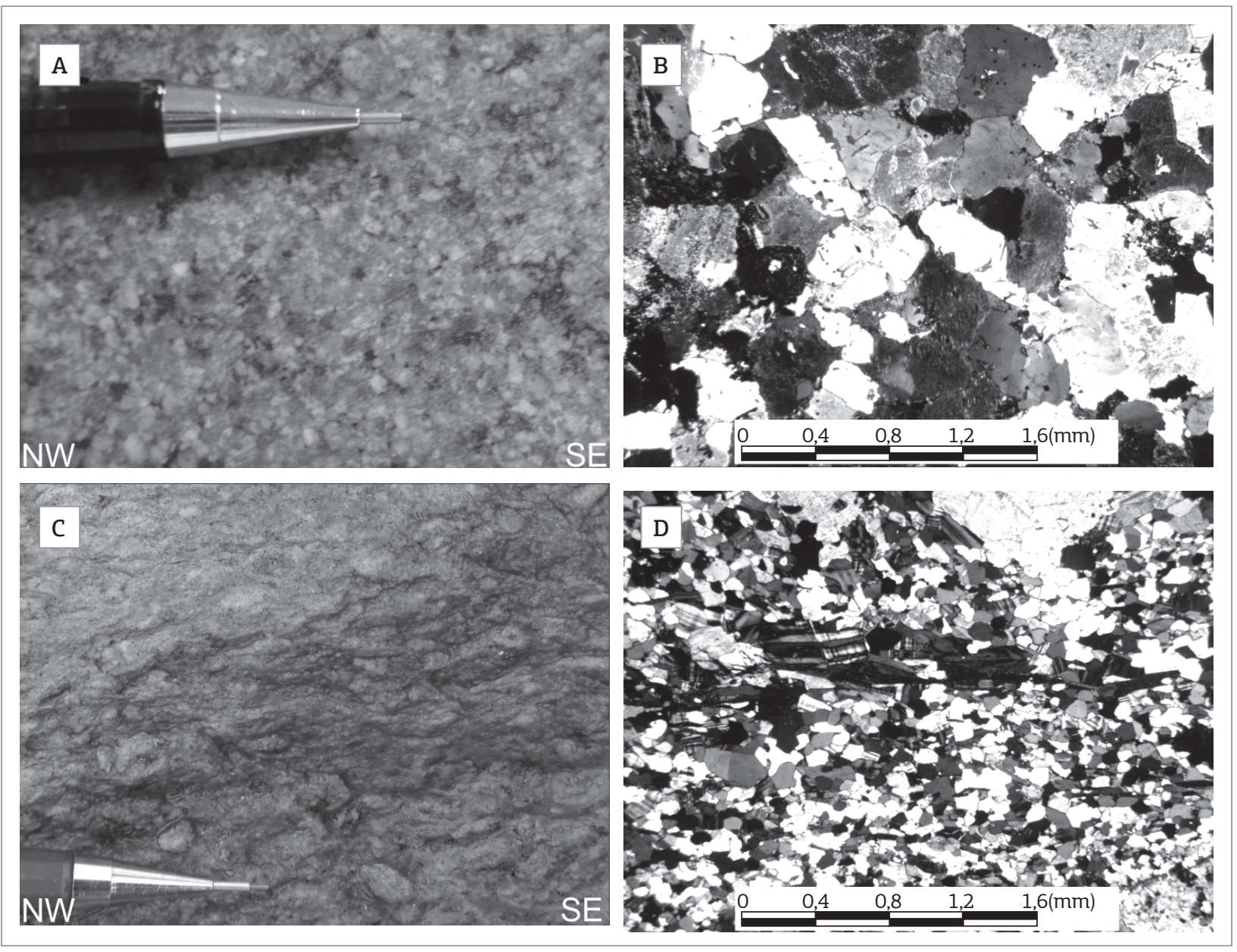

Figure 5. (A) $\mathrm{S}_{1}$ penetrative foliation outside the Esperança Shear Zone, represented by thin and discrete preferential reorientation of the felsic minerals; (B) photomicrograph of the $\mathrm{S}_{1}$ foliation outside the Esperança Shear Zone, showing little or no orientation of felsics and aggregates of biotite; (C) $\mathrm{S}_{1 \mathrm{~m}}$ foliation in the mylonitic rocks, represented by orientation, flattening, and rotation of the felsics of the matrix (alkali feldspar and quartz); (D) photomicrograph of the mylonitic rocks, displaying microcline and quartz crystals and slightly stretched and biotite-oriented plates.

with intracrystalline deformation marked by undulating extinction, lamellae, and bands of deformation, recrystallization, and formation of subgrains. The plagioclase occurs in tabular crystals and displays curving twin lamella from the brittle-ductile deformation. The biotite forms aggregates with chlorite, epidote, and opaque dispersed by the blade with a slight preferred orientation. The few measurements of $S_{1}$ foliation are concentrated between $90^{\circ} / 70^{\circ}$ and $70^{\circ} / 80^{\circ}$.

The Esperança Shear Zone, defined in this study, surrounds the eastern edge of the batholith and places it in contact with the metasediments of the Amolar Group, being mostly covered by the sediments from the Pantanal Formation. The structural elements related to this zone comprise the $S_{1 \mathrm{~m}}$ foliation and the $\mathrm{L}_{1 \mathrm{~m}}$ lineation, the first being defined by mineral orientation, flattening, and rotation of porphyroclasts (Fig. 5C).
In the microscope, the mylonitic rocks of the Esperança Shear Zone show well-oriented and slightly stretched minerals (Fig. 5D). The microcline crystals evidence intracrystalline deformation marked by recrystallization, as well as orientation and stretching. The quartz displays intense recrystallization, formation of subgrains, and undulating extinctions and lamellae of deformation. The biotite appears in strongly oriented veins according to the mylonitic foliation plane. The mylonitic rocks show an average attitude of $110^{\circ} / 45^{\circ}$, with variation between $100^{\circ}$ and $130^{\circ}$ in the direction of the dive, and dives between $55^{\circ}$ and $84^{\circ}$.

The $\mathrm{L}_{1 \mathrm{~m}}$ lineation of stretching, is defined by the elongation of felsic minerals according to the orientation of the $x$-axis of the ellipsoid of deformation, as it is slightly oblique relative to the mylonitic foliation, shown falling to approximately $50^{\circ}$ between the $100^{\circ}$ and $80^{\circ}$ azimuths. 
Dalila PexePlens et al.

Table 2. Results from the chemical analysis of the Cerro Porã Granite rocks. Major oxides were recalculated on an anhydrous basis (oxides in weight \%, trace elements in ppm)

\begin{tabular}{|c|c|c|c|c|c|c|c|c|c|c|}
\hline Elem. & DP-26B & DP-90A & DP-88 & DP-90 1 & DP-70 & DP-23 & DP-22A & DP-72 & DP-22B & DP-80 \\
\hline $\mathrm{SiO}_{2}$ & 70.14 & 70.79 & 71.17 & 71.69 & 73.32 & 74.72 & 74.86 & 74.87 & 74.88 & 74.90 \\
\hline $\mathrm{TiO}_{2}$ & 0.57 & 0.60 & 0.56 & 0.56 & 0.32 & 0.32 & 0.32 & 0.33 & 0.34 & 0.33 \\
\hline $\mathrm{Al}_{2} \mathrm{O}_{3}$ & 14.49 & 14.10 & 14.00 & 13.64 & 13.78 & 12.94 & 12.84 & 12.53 & 12.83 & 12.87 \\
\hline $\mathrm{Fe}_{2} \mathrm{O}_{3}$ & 4.16 & 3.75 & 3.59 & 3.76 & 2.02 & 1.76 & 1.66 & 2.32 & 1.71 & 1.72 \\
\hline $\mathrm{MnO}$ & 0.07 & 0.07 & 0.06 & 0.07 & 0.05 & 0.04 & 0.05 & 0.08 & 0.05 & 0.05 \\
\hline $\mathrm{MgO}$ & 0.58 & 0.58 & 0.58 & 0.59 & 0.20 & 0.17 & 0.20 & 0.15 & 0.17 & 0.18 \\
\hline $\mathrm{CaO}$ & 1.40 & 1.29 & 1.36 & 1.32 & 0.91 & 0.69 & 0.61 & 0.60 & 0.72 & 0.73 \\
\hline $\mathrm{Na}_{2} \mathrm{O}$ & 3.26 & 3.18 & 3.15 & 2.85 & 3.94 & 3.41 & 3.48 & 3.69 & 3.44 & 3.51 \\
\hline $\mathrm{K}_{2} \mathrm{O}$ & 5.09 & 5.27 & 5.19 & 5.12 & 5.11 & 5.61 & 5.61 & 5.01 & 5.43 & 5.38 \\
\hline $\mathrm{P}_{2} \mathrm{O}_{5}$ & 0.09 & 0.12 & 0.11 & 0.12 & 0.05 & 0.04 & 0.04 & 0.04 & 0.06 & 0.03 \\
\hline $\mathrm{Cr}_{2} \mathrm{O}_{3}$ & 0.00 & 0.00 & 0.00 & 0.00 & 0.00 & 0.00 & 0.00 & 0.00 & 0.00 & 0.00 \\
\hline Total & 99.85 & 99.74 & 99.76 & 99.72 & 99.71 & 99.70 & 99.67 & 99.62 & 99.63 & 99.71 \\
\hline LOI & 1.2 & 1.5 & 1.2 & 3.1 & 0.6 & 1.2 & 0.8 & 0.5 & 0.7 & 0.4 \\
\hline $\mathrm{Ba}$ & 566 & 601 & 604 & 619 & 1229 & 1079 & 1084 & 1272 & 1162 & 1184 \\
\hline Cs & 6.40 & 6.60 & 6.40 & 6.00 & 2.00 & 2.50 & 1.90 & 1.20 & 2.80 & 1.50 \\
\hline $\mathrm{Ga}$ & 20.30 & 20.00 & 20.40 & 19.20 & 16.30 & 15.70 & 15.70 & 17.10 & 15.50 & 15.30 \\
\hline $\mathrm{Hf}$ & 11.40 & 12.60 & 13.30 & 13.40 & 10.50 & 9.00 & 8.70 & 11.50 & 9.30 & 9.90 \\
\hline $\mathrm{Nb}$ & 20.80 & 21.70 & 21.50 & 19.10 & 16.90 & 17.90 & 18.80 & 16.40 & 20.00 & 19.10 \\
\hline $\mathrm{Rb}$ & 298.90 & 315.80 & 308.70 & 276.90 & 178.20 & 203.70 & 202.60 & 164.50 & 201.70 & 183.80 \\
\hline $\mathrm{Sr}$ & 77.50 & 82.40 & 81.30 & 79.60 & 90.10 & 66.20 & 55.80 & 75.10 & 68.70 & 72.70 \\
\hline $\mathrm{Ta}$ & 1.40 & 1.60 & 1.90 & 1.90 & 1.20 & 1.50 & 1.60 & 1.40 & 1.60 & 1.40 \\
\hline Th & 39.00 & 36.80 & 37.30 & 41.00 & 17.80 & 19.00 & 19.10 & 16.50 & 19.60 & 18.60 \\
\hline $\mathrm{U}$ & 8.00 & 8.40 & 9.20 & 9.10 & 3.70 & 3.90 & 3.80 & 3.80 & 4.10 & 3.90 \\
\hline $\mathrm{Zr}$ & 436.20 & 472.40 & 455.00 & 437.70 & 372.10 & 306.20 & 307.40 & 422.70 & 326.80 & 341.30 \\
\hline $\mathrm{Y}$ & 65.90 & 76.60 & 78.90 & 76.50 & 52.10 & 66.60 & 54.70 & 91.40 & 66.10 & 60.80 \\
\hline $\mathrm{La}$ & 73.40 & 70.40 & 73.80 & 80.80 & 54.30 & 65.80 & 56.20 & 87.00 & 66.60 & 60.90 \\
\hline $\mathrm{Ce}$ & 149.00 & 147.80 & 152.50 & 162.50 & 113.90 & 132.80 & 119.00 & 186.20 & 140.60 & 129.30 \\
\hline $\operatorname{Pr}$ & 17.08 & 16.91 & 17.35 & 18.65 & 12.29 & 15.10 & 13.58 & 21.39 & 16.13 & 14.78 \\
\hline $\mathrm{Nd}$ & 62.70 & 64.30 & 61.70 & 70.90 & 46.10 & 57.30 & 52.40 & 85.60 & 60.90 & 56.70 \\
\hline $\mathrm{Sm}$ & 11.39 & 11.69 & 12.32 & 13.23 & 8.49 & 10.34 & 9.47 & 16.26 & 11.35 & 10.57 \\
\hline $\mathrm{Eu}$ & 1.41 & 1.34 & 1.40 & 1.42 & 1.20 & 1.23 & 1.16 & 2.33 & 1.33 & 1.26 \\
\hline $\mathrm{Gd}$ & 10.31 & 11.28 & 11.65 & 12.74 & 7.43 & 9.29 & 8.58 & 15.55 & 10.64 & 9.48 \\
\hline $\mathrm{Tb}$ & 1.98 & 1.97 & 2.05 & 1.97 & 1.32 & 1.60 & 1.51 & 2.62 & 1.85 & 1.66 \\
\hline Dy & 11.73 & 12.04 & 12.40 & 13.31 & 7.99 & 9.69 & 9.12 & 15.11 & 11.01 & 9.94 \\
\hline Ho & 2.38 & 2.65 & 2.61 & 2.46 & 1.70 & 2.08 & 1.92 & 3.16 & 2.34 & 2.13 \\
\hline $\mathrm{Er}$ & 7.28 & 7.66 & 7.99 & 7.97 & 5.08 & 6.44 & 5.90 & 9.10 & 7.08 & 6.54 \\
\hline $\mathrm{Tm}$ & 1.15 & 1.17 & 1.27 & 1.13 & 0.86 & 1.03 & 0.94 & 1.39 & 1.11 & 1.01 \\
\hline $\mathrm{Yb}$ & 7.15 & 7.78 & 8.08 & 7.77 & 5.62 & 6.89 & 6.24 & 8.55 & 7.03 & 6.56 \\
\hline $\mathrm{Lu}$ & 1.09 & 1.18 & 1.26 & 1.16 & 0.87 & 1.06 & 0.95 & 1.26 & 1.09 & 1.03 \\
\hline $\mathrm{Eu} / \mathrm{Eu}^{*}$ & 0.4 & 0.36 & 0.36 & 0.33 & 0.46 & 0.38 & 0.39 & 0.45 & 0.37 & 0.38 \\
\hline$(\mathrm{La} / \mathrm{Yb}) \mathrm{N}$ & 7.36 & 6.49 & 6.55 & 7.46 & 6.93 & 6.85 & 6.46 & 7.3 & 6.8 & 6.66 \\
\hline
\end{tabular}




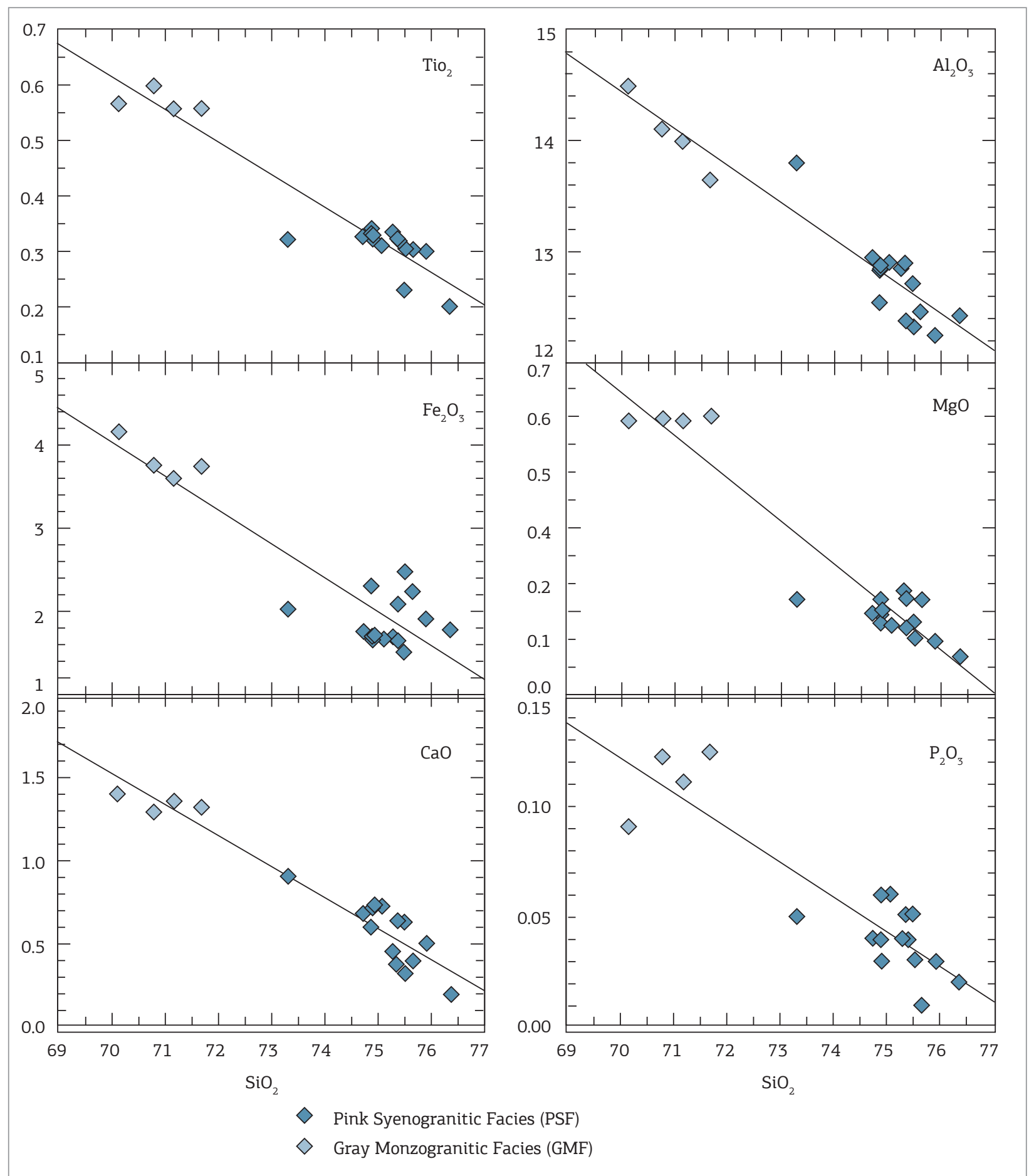

Figure 6. Harker variation diagrams for major elements expressed in oxides (\% weight) of rocks from the Cerro Porã Granite.

Analysis of the kinematic indicators suggests that the Esperança Shear Zone is classified as reverse, frontal to slightly oblique, and with transport from the top preferentially to $\mathrm{N} 70^{\circ}-90^{\circ} \mathrm{W}$.

The $\mathrm{F}_{1}$ deformational phase is accompanied by $\mathrm{M}_{1}$ regional metamorphism, and the metamorphic conditions given by the quartz+biotite+chlorite+epidote paragenesis point to a low degree compatible with green schist facies.

The brittle tectonic is represented by sets of fractures and small faults observed in all of the intrusions with an average attitude of $230^{\circ} / 80^{\circ}$. These structures are oriented orthogonally to the length of the batholith, are shown with directions correlatable to the $S_{2}$ foliation of the volcanoclastic 


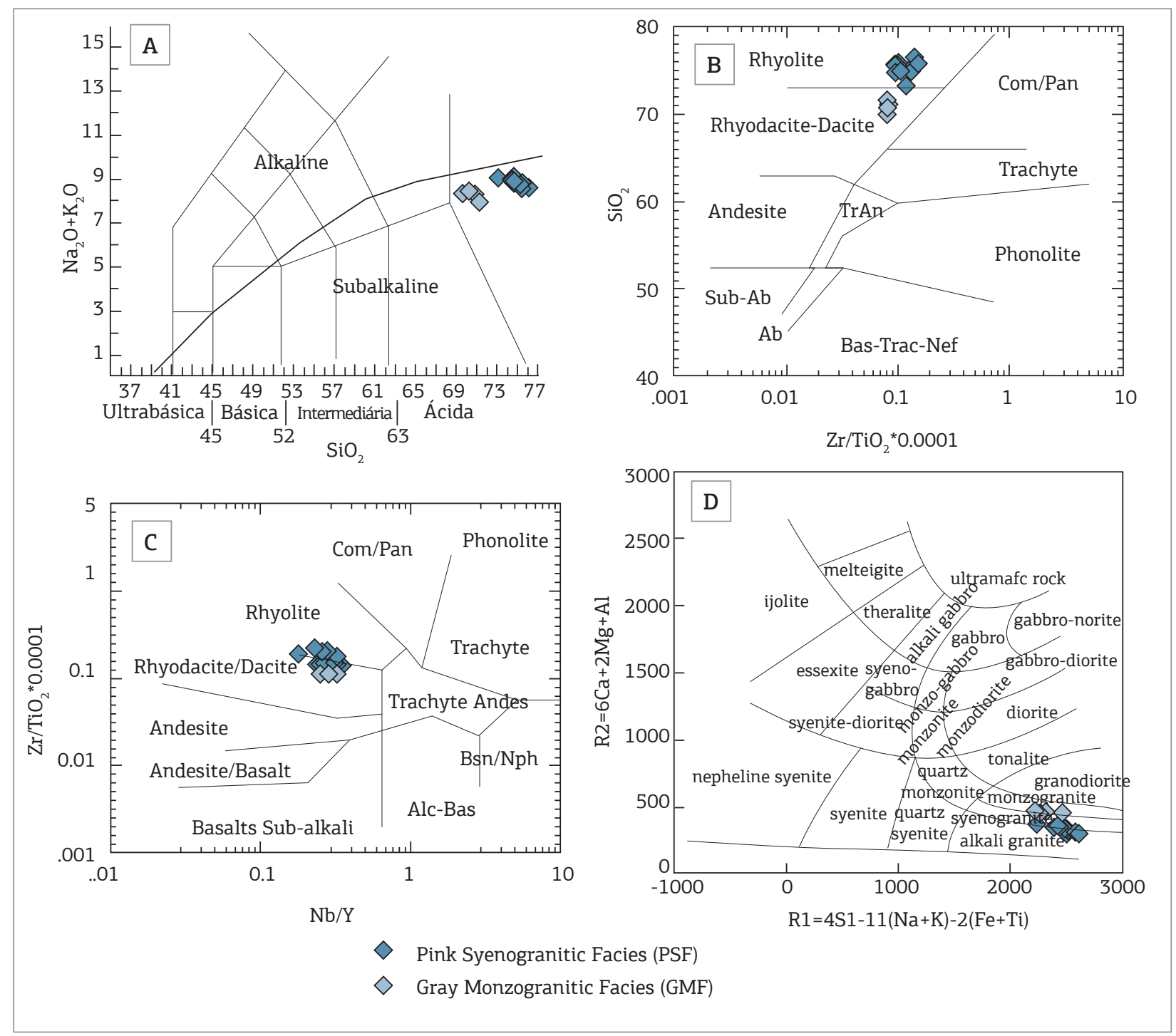

Figure 7. Compositional variation of the Cerro Porã Granite rocks in the diagrams: (A) alkalis versus silica (Le Bas et al. 1986), with a limit between the alkaline/subalkaline domains of Irvine and Baragar (1971); (B and C) respectively, $\mathrm{SiO}_{2}$ versus $\mathrm{Zr} / \mathrm{TiO}_{2}$ andZr/TiO 2 versus $\mathrm{Nb} / \mathrm{Y}$, proposed by Winchester and Floyd (1977) and (D) R1-R2 (La Roche 1980).

rocks of the Serra da Bocaina Formation, and are probably associated with the regional lineaments of the NW direction observed in the CPG (Fig. 2). Microscopically, these fractures are displayed with veins filled by alteration minerals represented by a large quantity of sericite, with epidote and a concentration of iron oxide/hydroxide.

\section{GEOCHEMICAL CHARACTERIZATION}

For the geochemical study of rocks from the CPG, 19 of the most representative samples from this unit were analyzed, considering their distribution in the study area and their textural and mineralogical diversity -15 samples were from the PSF and 4 samples were from the GMF. After being crushed and pulverized in the Sample Preparation Laboratory of the Department of Mineral Resources of the Universidade Federal do Mato Grosso, these samples were sent to the Acme Analytical Laboratories (Acmelab) - Vancouver/ Canada for analyses by Inductively Couple Plasma Emission Spectrometry (ICP-ES) and Inductively Couple Plasma Mass Spectrometry (ICP-MS) for major and minor elements $\left(\mathrm{SiO}_{2}, \mathrm{TiO}_{2}, \mathrm{Al}_{2} \mathrm{O}_{3}, \mathrm{Fe}_{2} \mathrm{O}_{3}, \mathrm{MnO}, \mathrm{MgO}, \mathrm{CaO}, \mathrm{Na}_{2} \mathrm{O}, \mathrm{K}_{2} \mathrm{O}\right.$, and $\mathrm{P}_{2} \mathrm{O}_{5}$ ) and for trace elements, including rare earth elements. For statistical analysis, the major elements were recalculated on an anhydrous basis as recommended by the IUGS (Le Maitre 2002), and these results, associated with the other findings, are presented in Table 2. 


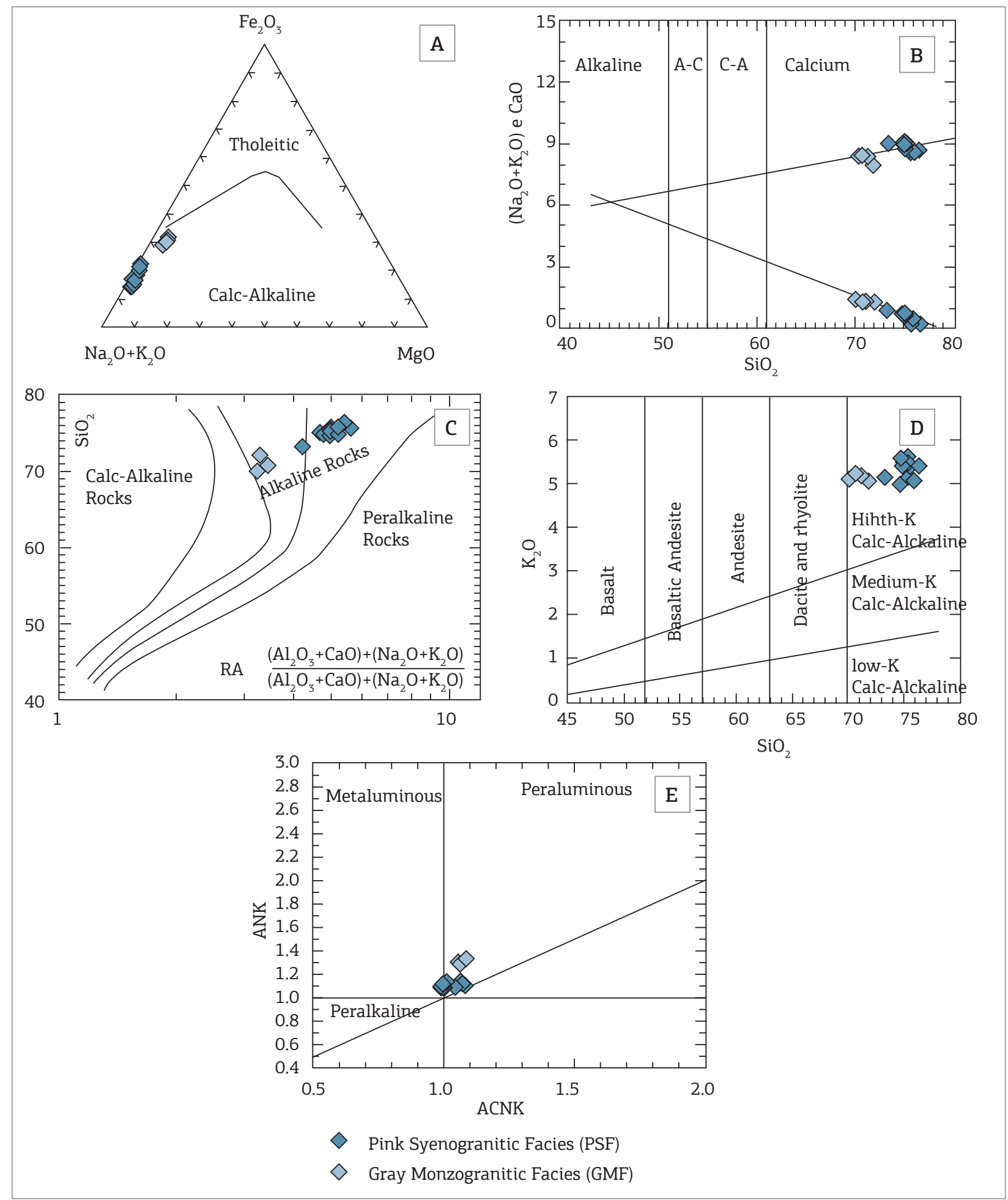

Figure 8. Distribution of the representative points of the Cerro Porã Granite granite rocks in the diagrams: (A) AFM (Irvine \& Baragar 1971); (B) total alkalis and $\mathrm{CaO}$ versus silica (Peacock 1931); (C) $\left(\mathrm{Al}_{2} \mathrm{O}_{3}+\mathrm{CaO}\right)+\left(\mathrm{Na}_{2} \mathrm{O}+\mathrm{K}_{2} \mathrm{O}\right) /$ $\left(\mathrm{Al}_{2} \mathrm{O} 3+\mathrm{CaO}\right)-\left(\mathrm{Na}_{2} \mathrm{O}+\mathrm{K}_{2} \mathrm{O}\right.$ ) versus silica (Whright 1969); (D) $\mathrm{K}_{2} \mathrm{O}$ versus $\mathrm{SiO}_{2}$ (Le Maitre 2002); and (E) $\mathrm{A} / \mathrm{NK}$ versus $\mathrm{A} /$ CNK (Maniar \& Piccoli 1989).

CPG rocks have a slightly expanded acidic nature, with concentrations of $\mathrm{SiO}_{2}$ between $70.14 \%$ and $76.35 \%$, with values between $70.14 \%$ and $71.69 \%$ for the samples from the GMF and $73.32 \%$ and $76.35 \%$ for the PSF. The Harker diagrams (Fig. 6) indicate negative linear correlations between silica and $\mathrm{TiO}_{2}, \mathrm{Al}_{2} \mathrm{O}_{3},\left(\mathrm{Fe}_{2} \mathrm{O}_{3}\right)_{\mathrm{t}}$, 


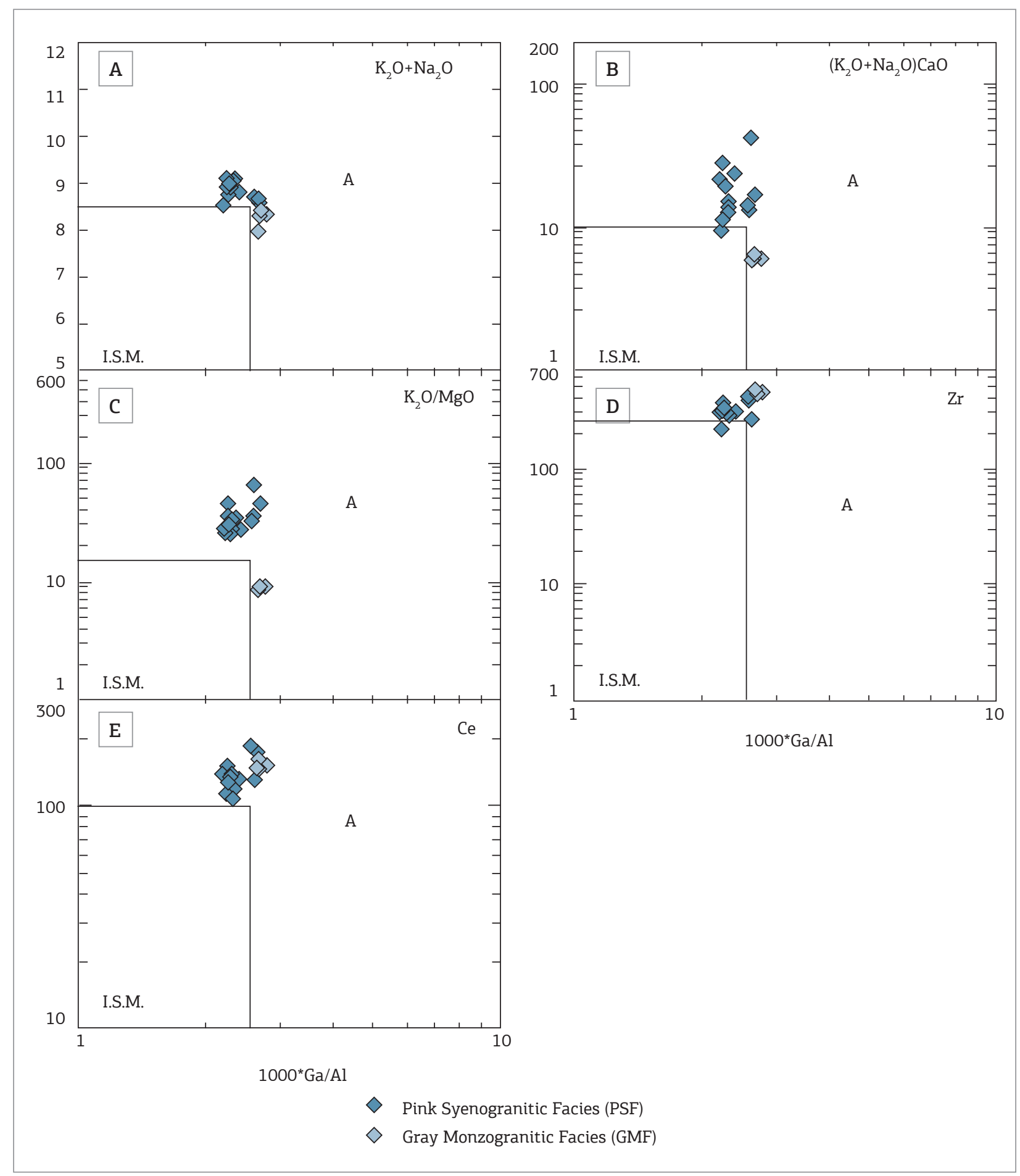

Figure 9. Distribution of the representative points of the CPG rocks in the diagrams proposed by Whalen et al. (1987): $10,000 * \mathrm{Ga} / \mathrm{Al}$ versus $\mathrm{K}_{2} \mathrm{O}+\mathrm{Na}_{2} \mathrm{O}(\mathrm{A}) ;\left(\mathrm{K}_{2} \mathrm{O}+\mathrm{Na}_{2} \mathrm{O}\right) / \mathrm{CaO}(\mathrm{B}) ; \mathrm{K}_{2} \mathrm{O} / \mathrm{MgO}(\mathrm{C}) ; \mathrm{K}_{2} \mathrm{O} / \mathrm{MgO}$; (D) $\mathrm{Zr}$; and (E) Ce. The rectangular boxes refer to the I, S, and $\mathrm{M}$-type granites and the coordinates to the same are: $x=2.6, Y=8.5(\mathrm{~A})$, 10 (B), 16 (C), 270 (D), and 100 (E).

$\mathrm{MgO}, \mathrm{CaO}$, and $\mathrm{P}_{2} \mathrm{O}_{5}$ that must reflect the depletion in plagioclase and in primary mafic materials, such as biotite, titanite, Fe-Ti oxides, and apatite during magmatic evolution. Samples from less-evolved facies (GMF) do not show variations in the $\mathrm{TiO}_{2}$ and $\mathrm{MgO}$ elements with the index used, and $\mathrm{P}_{2} \mathrm{O}_{5}$ shows a discrete positive correlation. The diagrams that involve the alkalis do not exhibit a correlation with the silica, most likely caused by the greater mobility of these elements in the post-magmatic processes. 


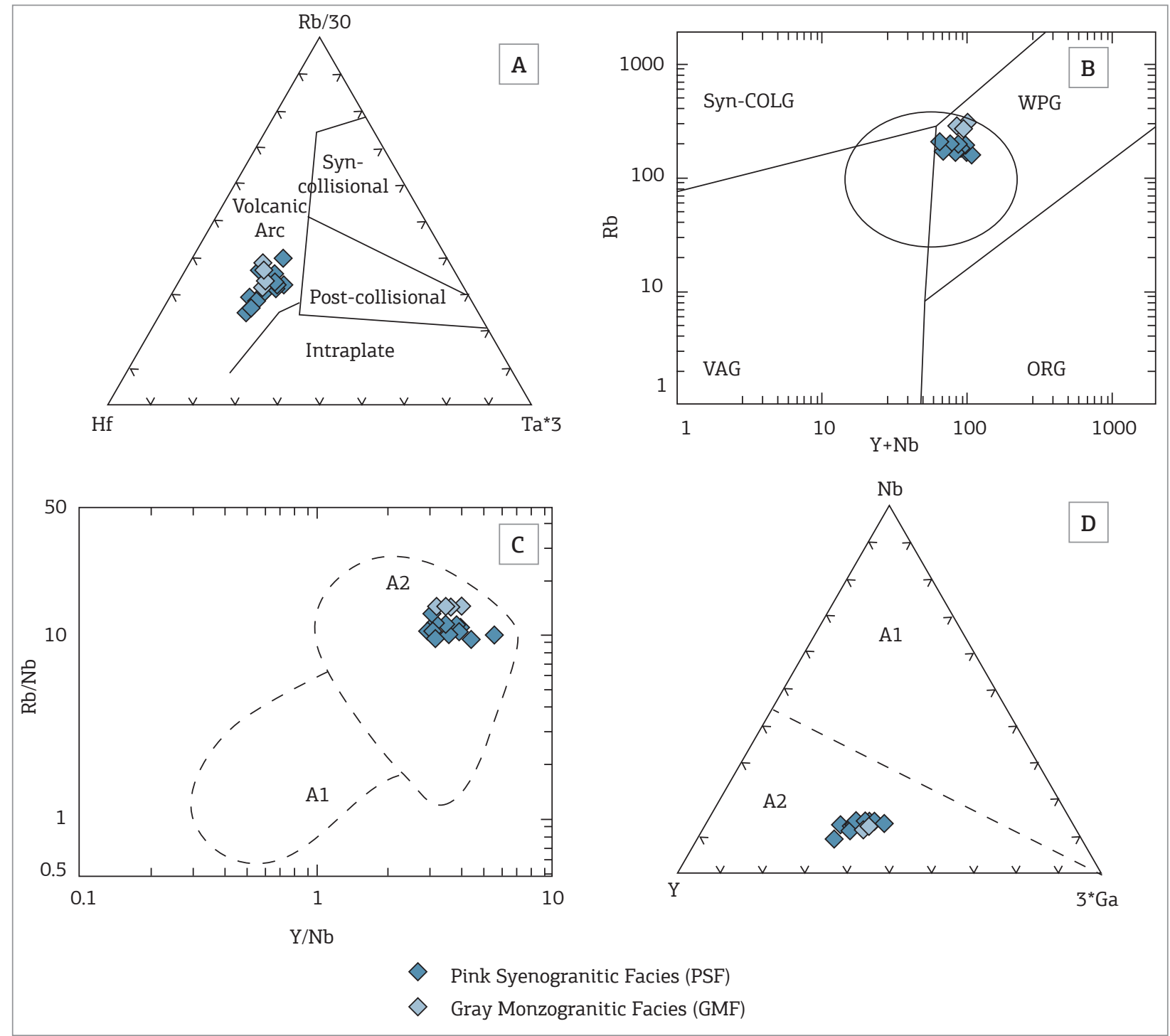

Figure 10. Distribution of the representative points of the Cerro Porã Granite rocks in the diagrams: (A) Hf- $\mathrm{Rb} / 30-\mathrm{Ta} * 3$ (Harris et al. 1986); (B) Rb versus $\mathrm{Y}+\mathrm{Nb}$ (Pearce et al. 1996); (C)Rb/Nb versus $\mathrm{Y} / \mathrm{Nb}$; and (D) $\mathrm{Y}-\mathrm{Nb}-3^{*} \mathrm{Ga}$ (Eby 1992).

By using the diagrams proposed for volcanic rocks, the CPG samples coincide with the domain of rhyolites in the diagram of alkalis versus silica of Le Bas et al. (1986; Fig. 7A). In a similar manner, they are plotted in the field of rhyodacites/dacites and rhyolites in those from Winchester and Floyd (1977) that use, in addition to $\mathrm{SiO}_{2}$, ratios of elements considered to be less mobile in the post-magmatic processes, such as $\mathrm{Zr} / \mathrm{TiO}_{2}$ and $\mathrm{Nb} / \mathrm{Y}$ (Figs. $7 \mathrm{~B}$ and $\mathrm{C}$ ). Corroborating the petrographic study, the points that represent the GMF lithotypes coincide with the domains of the monzogranites and those of the PSF with those of the syenogranites and alkali granites, in the R1-R2 diagram (La Roche 1980; Fig. 7D).

The total diagrams of alkalis versus $\mathrm{SiO}_{2}$ and AFM from Irvine and Baragar (1971), which are illustrated, respectively, in Figs. 7A and 8A, indicate that the magmatism that produced the studied rocks is characterized as sub-alkaline of the calcium-alkaline type with enrichment in alkalis from the more evolved terms. In the Peacock diagram (1931; Fig. 8B), the intersection of the trends of the total alkalis and $\mathrm{CaO}$ versus $\mathrm{SiO}_{2}$ coincides with the alkaline domain with an Alkali-Calcic Index around 45 . This classification is corroborated by the silica versus Whright Index (RA; Fig. 8C), which also considers alumina and where the samples from both of the facies are plotted on the field of the alkaline rocks. The high-K nature of this magmatism is shown in the $\mathrm{K}_{2} \mathrm{O}$ versus $\mathrm{SiO}_{2}$ diagram (Le Maitre 2002; Fig. 8D), whereas in relation to the Shand indices, which are used in the A/CNK versus A/NK diagram (Maniar \& Piccoli 1989; Fig. 8E), the distribution of the representative points of the CPG classifies this magmatism as peraluminous. 

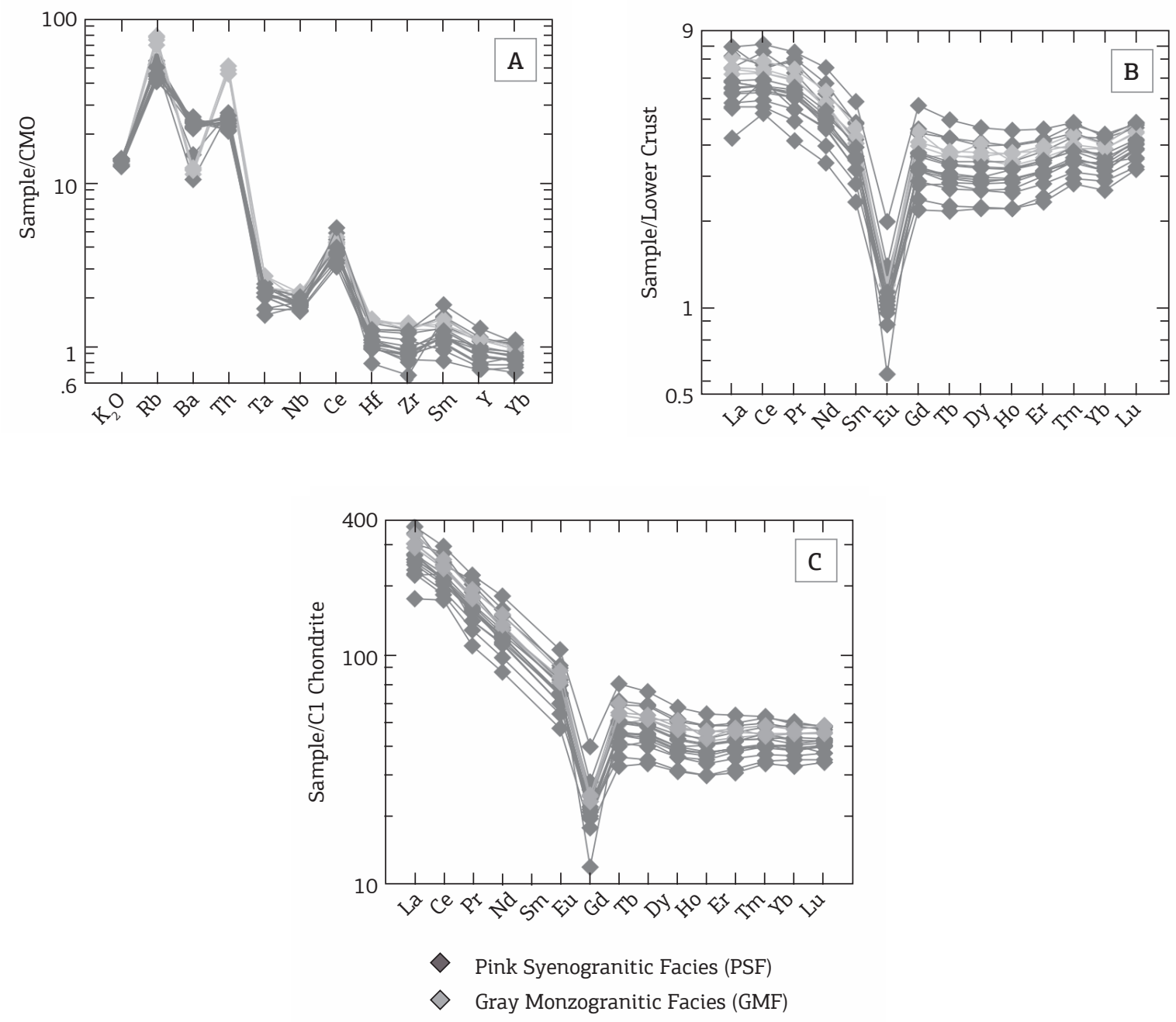

Figure 11. Distribution patterns of the Cerro Porã Granite rocks in the diagrams: (A) Trace elements and $\mathrm{K}_{2} \mathrm{O}$ normalized by the values of granites from the Mid-Oceanic Ridges of Pearce et al. (1984); (B) REE normalized by the values from the lower crust (Taylor \& McLennan 1985); and (C) REE normalized by the C1 chondrite (Sun \& Mac Donough 1989).

The values of the ratio $10,000 * \mathrm{Ga} / \mathrm{Al}$ of the $\mathrm{CPG}$ rocks used as discriminants, as proposed by Whalen $e$ al . (1987), classify them as A-type granitoids, characterized by this parameter being higher than 2.6 (Fig. 9).

Regarding the geotectonic environment, the representative points of the studied rocks coincide with the domain proposed for the Magmatic Arc in the Hf-Rb-Ta diagram of Harris et al. (1986; Fig. 10A) and with the post-orogenic granitoids in the diagram by Pearce (1996; Fig. $10 \mathrm{~B})$. When the graphs $\mathrm{Rb} / \mathrm{Nb}$ versus $\mathrm{Y} / \mathrm{Nb}$ and Y-Nb-3*Ga, proposed by Eby (1992; Figs. 10C and D) are used, these points are plotted in the field of group A2 granitoids that, according to this author, encompass some tectonic environments, including the post-collisional ones.
The pattern of trace elements associated with the $\mathrm{K}_{2} \mathrm{O}$ data from the studied rocks, normalized with the values from granites from the Mid-Ocean Ridge (Pearce et al. 1984; Fig. 11A), shows enrichment of the large ionic lithophyllic elements in relation to the high field strength elements. The large ionic lithophyllic elements show positive anomalies of $\mathrm{Rb}$ and Th, suggesting an important crustal component, and the high field strength elements display a sub-horizontal trace, with the exception of $\mathrm{Ce}$, which exhibits a positive anomaly relative to the neighboring elements ( $\mathrm{Nb}$ and $\mathrm{Hf}$ ).

The concentrations of rare earth elements in the CPG rocks normalized to the lower crust values (Taylor \& McLennan 1985), illustrated in Fig. 11B, display a configuration similar to that found in alkaline suites with a negative $\mathrm{Eu}$ anomaly and with $\mathrm{Eu} / \mathrm{Eu}^{*}$ ratios between 0.19 and 0.46 , 


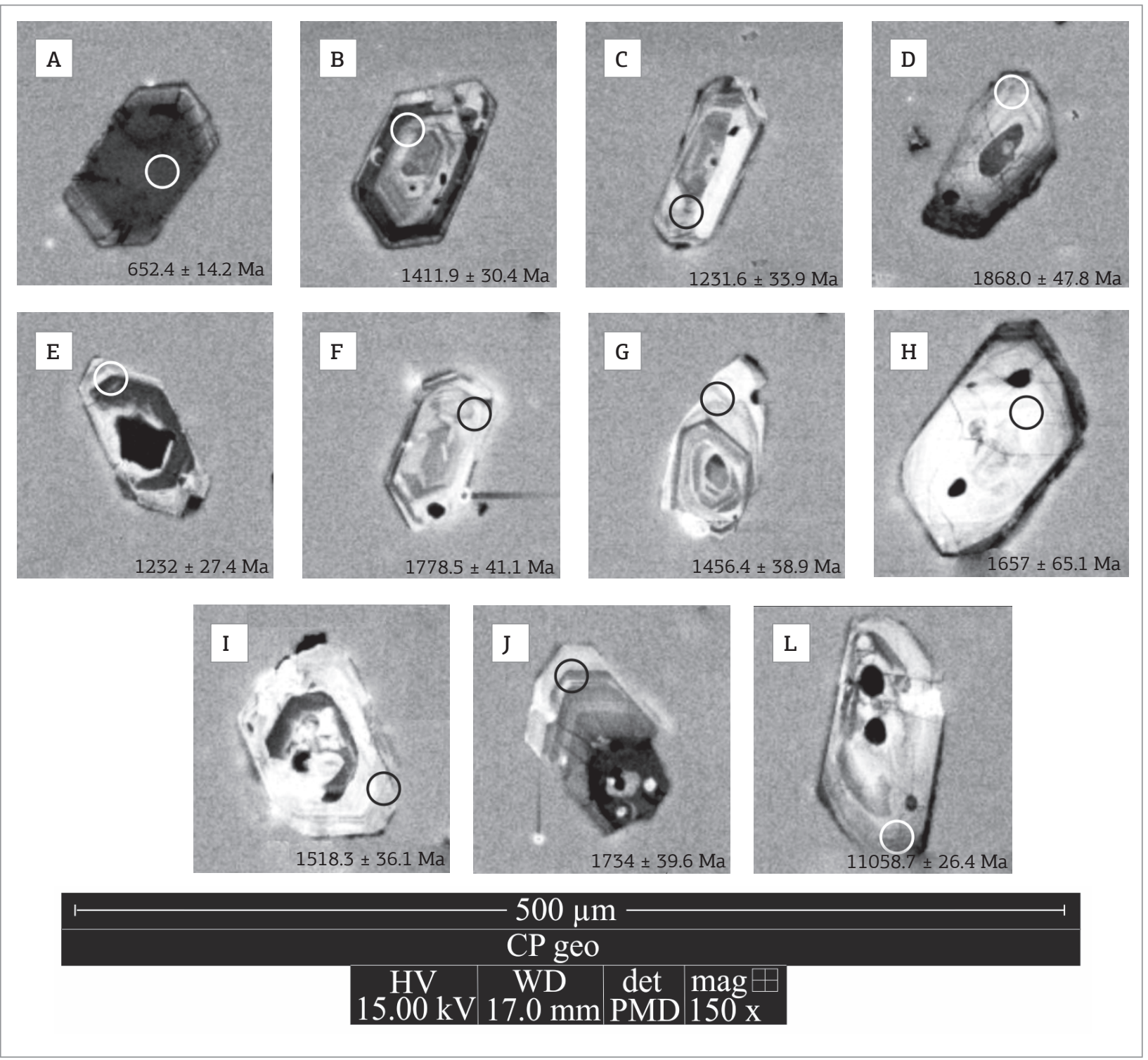

Figure 12. CL image of zircon crystals (A) DP22B 1.1, (B) DP22B 2.1, (C) DP22B 3.1, (D) DP22B 4.1, (E) DP22B 5.1, (F) DP22B 6.1, (G) DP22B 7.1, (H) DP22B 8.1, (I) DP22B 9.1, (J) DP22B 10.1, and (L) DP22B 11.1. The image also illustrates the application sites of the primary ionizing beam.

which corroborates the hypothesis of magmatic differentiation with fractioning of plagioclase. When normalized using chondritic values (C1; Sun \& Mac Donough 1989; Fig. 11C) fractioning of the HREE in relation to the LREE is observed, with $(\mathrm{La} / \mathrm{Yb}) \mathrm{n}$ ratios between 5.07 and 7.30 for the samples from the PSF and 6.49 and 7.46 for the GMF (Table 2), besides sub-horizontalized disposition of the ETRP.

\section{U-PB GEOCHRONOLOGY (SHRIMP)}

The CPG geochronological study was performed through the DP 22 B sample, which was collected near the Milênio Farm (FazendaMilênio). The analyzed sample is located on the southern portion of the body (relatively close to the contact with the Amolar Group) and belongs to the PSF.

The collected sample was treated in the Sample Preparation Laboratory of the Department of Mineral Resources of the Federal University of MatoGrosso. Initially, the sample was crushed in a jaw crusher, ground in a disc mill, and sifted in 250,210, 177, 125, 90, and 63 mesh fractions, using a set of sieves. The concentrate from the 90 mesh was used for analysis, and the remaining intervals were kept for later uses. Magnetic minerals such as magnetite and pyrrhotite were removed using a hand magnet. Subsequently, a processing stage occurred in a dense bromoform liquid $\left(d=2.85 \mathrm{~g} / \mathrm{cm}^{3}\right)$, which 
Dalila PexePlens et al.

Table 3. Synthesis of the data obtained through U/Pb (SHRIMP) analysis in zircons for the DP $22 \mathrm{~B}$ sample

\begin{tabular}{|c|c|c|c|c|c|c|c|c|c|c|c|c|}
\hline $\begin{array}{l}\text { Grain's } \\
\text { Simbol }\end{array}$ & $\underset{(\mathrm{ppm})}{\mathrm{U}}$ & $\begin{array}{c}\text { Th } \\
\text { (ppm) }\end{array}$ & $\begin{array}{l}{ }^{232} \mathrm{Th} / \\
{ }^{238} \mathrm{U}\end{array}$ & $\begin{array}{c}{ }^{206} \mathrm{~Pb} \\
\text { commom }\end{array}$ & $\begin{array}{c}\text { Reason } \\
{ }^{207} \mathrm{~Pb} / \\
{ }^{235} \mathrm{U}\end{array}$ & $\%$ error & $\begin{array}{c}\text { Reason } \\
{ }^{206} \mathrm{~Pb} /{ }^{238} \mathrm{U}\end{array}$ & $\begin{array}{c}\% \\
\text { error }\end{array}$ & $\begin{array}{l}\text { Correted } \\
\text { Error }\end{array}$ & $\begin{array}{l}\text { Age } \\
\text { Ma }\end{array}$ & $\pm 1 \mathrm{~s}$ & $\%$ disc \\
\hline 1.1 & 3093 & 3966 & 1.32 & 4.89 & 1.09 & 8.6 & 0.108 & 2.1 & 0.246 & 652.4 & 14.2 & 56 \\
\hline 2.1 & 382 & 238 & 0.65 & 3.17 & 3.48 & 5.2 & 0.247 & 2.2 & 0.418 & 1411.9 & 30.4 & 17 \\
\hline 3.1 & 206 & 123 & 0.62 & 11.00 & 2.62 & 19.8 & 0.210 & 2.7 & 0.136 & 1231.6 & 33.9 & 17 \\
\hline 4.1 & 206 & 184 & 0.92 & 9.17 & 4.69 & 15.8 & 0.326 & 2.6 & 0.164 & 1868.0 & 47.8 & -6 \\
\hline 5.1 & 521 & 525 & 1.04 & 3.63 & 3.09 & 5.6 & 0.215 & 2.2 & 0.396 & 1232.0 & 27.4 & 35 \\
\hline 6.1 & 129 & 104 & 0.83 & 2.04 & 4.52 & 4.8 & 0.315 & 2.4 & 0.496 & 1778.5 & 41.1 & -4 \\
\hline 7.1 & 150 & 66 & 0.45 & 9.28 & 3.69 & 15.0 & 0.254 & 2.7 & 0.180 & 1456.4 & 38.9 & 18 \\
\hline 8.1 & 54 & 42 & 0.81 & 4.01 & 4.79 & 9.4 & 0.296 & 4.1 & 0.437 & 1657.0 & 65.1 & 15 \\
\hline 9.1 & 221 & 123 & 0.58 & 6.76 & 3.36 & 12.5 & 0.262 & 2.5 & 0.198 & 1518.3 & 36.1 & -1 \\
\hline 10.1 & 153 & 106 & 0.71 & 2.30 & 4.65 & 4.8 & 0.308 & 2.3 & 0.487 & 1734.0 & 39.6 & 3 \\
\hline 11.1 & 193 & 124 & 0.66 & 4.70 & 2.78 & 8.1 & 0.185 & 2.5 & 0.305 & 1058.7 & 26.4 & 63 \\
\hline
\end{tabular}

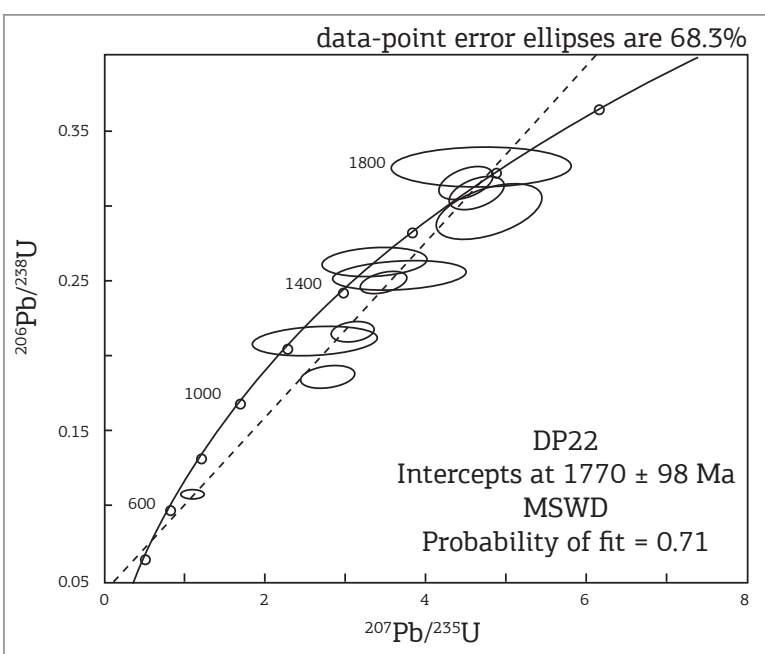

Figure 13. U/Pb (SHIRIMP) Concordia diagram for the DP 22 B sample from the Cerro Porã Granite granite, showing the concordant age in the superior intercept at $1770 \pm 98 \mathrm{Ma}$, which is interpreted as the age of crystallization of the granitic body.

yielded the zircon concentrate. Next, the minerals with different magnetic susceptibilities were concentrated in a Frantz-type magnetic separator, varying the slope and the intensity of the electromagnetic field to eliminate the majority of the magnetic minerals, such as biotite, pyroxene, and amphibole. Of the resulting material, 100 zircons were separated manually under an Olympus BX50 binocular microscope in the Microscope Laboratory of the DRM/UFMT.

The SHRIMP equipment is a high-resolution mass spectrometer coupled to an ionic microprobe. It allows for the performance of isotopic analyses of $\mathrm{U}$ and $\mathrm{Pb}$ of zircon "in situ" and, therefore, the dating of zircon

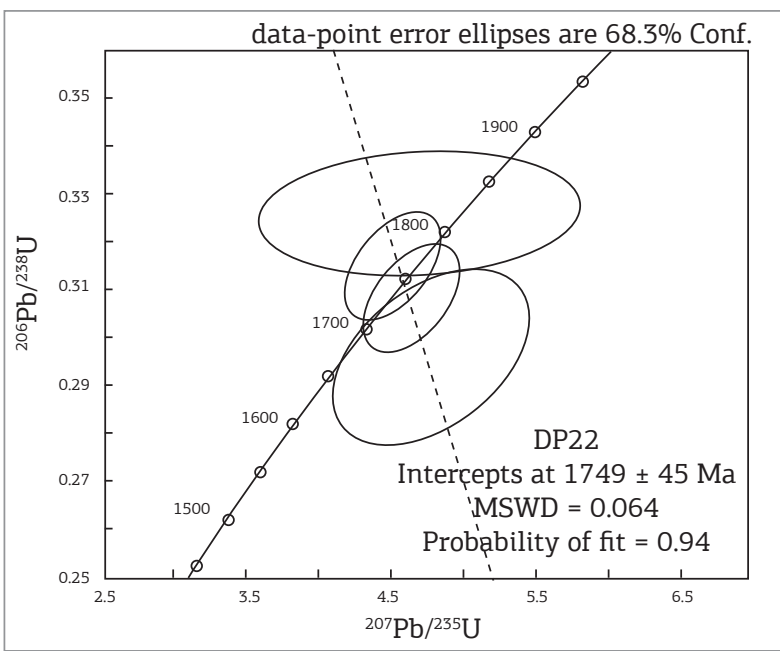

Figure 14. Concordia diagram U/Pb (SHIRIMP) from the DP 22 B sample, revealing a concordant age by the superior intercept of $1749 \pm 45 \mathrm{Ma}$, elaborated with four crystals of zircons to reduce the error of common lead correction.

crystals that shows multiple phases of growth. To this end, a previous study of cathodoluminescence is necessary (Sato et al. 2008).

Isotopic U-Pb (SHIRIMP) data in zircon were obtained in the laboratory of the Center of Geochronological Research of the Universidade de São Paulo, using a $30-\mu \mathrm{m}$-diameter beam of $\mathrm{O}_{2}$. Details of the analytical procedures and calibration of the equipment are described in Stern (1998) and Williams (1998). The error on the ${ }^{206} \mathrm{~Pb} /{ }^{238} \mathrm{U}$ ratio is between $1.5 \%$ and $2.0 \%$ of the calibration of the measurements when standard zircons are used. The concentration of $U$ was calibrated in relation to a standard SL13 crystal with 238 ppm U $(< \pm 10 \%)$, and 
the $\mathrm{Pb} / \mathrm{U}$ ratio was calibrated relative to an AS57 standard multi-crystal of $1100 \mathrm{Ma}$ (Paces \& Miller 1993). All of the errors take into consideration the non-linear fluctuations in the rates of ionic counting, in addition to those expected by statistical counting (Stern 1998).

The decay constants and current ratio of ${ }^{238} \mathrm{U} / 235 \mathrm{U}$ used in the calculations are those provided by Steiger and Jäger (1977). For the calculation of the integrated age, weighted averages were made having as a basis the interpretation of the cathodoluminescence images belonging to the same generation of zircon. The ages were calculated using the Isoplot/EX program from Ludwig (1998) and are represented in the Concordia diagram.

Of the manually selected zircon crystals, 11 grains were used to obtain scanning electron microscope photographs and the subsequent analysis. The zircon crystals was characterized morphologically as shirt prismatic crystals, with approximate dimensions between 80 and $130 \mu \mathrm{m}$, where the length versus width relationship was $2 / 1$, and a minority of the grains displayed this relationship as $1 / 1$. The grains had prismatic, light yellow, smoky, whitish, and orange colors, varying from transparent to opaque, and some of the crystals were fractured and broken.

The cathodoluminescence images used to delineate the most appropriate area for applying the primary ionizing beam revealed that crystals 1.1, 2.1, 3.1, 4.1, 5.1, 6.1, 9.1, 10.1, and 11.1 exhibited relatively regular bands of light and dark zoning that were interpreted as variations of the chemical concentrations of $U$ (Sato et al. 2008). Crystal 7.1 displayed two phases of growth, with the core and the edge highlighted with homogeneous overgrowth and not showing bands of chemical zoning, and crystal 8.1 was homogeneous and clear and lacked internal zoning (Fig. 12).

The results obtained are presented in Table 3 , and the values vary from $652.4 \pm 14.2$ to $1868.0 \pm 47.8 \mathrm{Ma}$. In the Concordia diagram (Fig. 13), the analyzed zircons provide a concordant age of $1770 \pm 98 \mathrm{Ma}$ (between 1672 and $1868 \mathrm{Ma}$ ).

To reduce the error caused by the large amount of common lead from the zircons analyzed, a new age calculation was determined from the values of concordant ages, corresponding to crystals 4.1, 6.1, 8.1, and 10.1. In the Concordia diagram the analytical points provide age of $1749 \pm 45 \mathrm{Ma}$ (between 1704 and $1794 \mathrm{Ma}$; Fig. 14), which is interpreted as the best estimate of the age of crystallization of the granitic body.

\section{FINAL CONSIDERATIONS}

The Rio Apa Terrane comprises a Paleoproterozoic crustal segment corresponding to the southern portion of the Amazonian Craton and is characterized by crustal evolution processes marked by accretions of juvenile crust. The CPG belongs to the Alumiador Intrusive Suite and most likely constitutes one of the last late igneous-tectonic events related to the Amoguijá Magmatic Arc.

The CPG defines a batholith elongated in the NNE direction, with an approximate area of $30 \mathrm{~km}$ by $4 \mathrm{~km}$, and consists of PSF and GMF, which are both metamorphosed into green schist facies. The PSF is characterized by a texture that is essentially equal to xenomorphic inequigranular and the constant presence of graphic and granophyric intergrowths and that consists of alkali feldspars, quartz, and plagioclase, with biotite as the only primary mafic. The monzogranitic facies are composed of quartz, plagioclase, alkali feldspar, and mafic aggregates (amphibole, biotite, and opaques). When in shear zones, they show a porphyroclastic texture formed by alkali feldspars, quartz, and plagioclase with a well-defined mylonitic foliation.

The structural data indicate that the CPG displays deformational records from a phase of ductile deformation $\left(F_{1}\right)$ represented by incipient foliation $\left(S_{1}\right)$ and intense mylonitization along the Esperança Shear Zone and a reverse character with top transportation to the NWW. Geochemical treatment allowed for classification of the rocks studied as monzogranites to syenogranites and alkaline granites, from the alkaline potassium silica-saturated series, with characteristics of A-type granitoids, alkaline to peraluminous, similar to that found in alkaline suites. Regarding the characterization of the tectonic setting of the studied rocks, representative points coincide with the field proposed for the magmatic arc and post-orogenic granites. Radiometric dating using the U-Pb (SHRIMP) zircon method provided an age of $1749 \pm 45 \mathrm{Ma}$ for its crystallization. Younger values between 1440 and $1230 \mathrm{Ma}$ were interpreted as resulting from an adjustment of the $\mathrm{U}-\mathrm{Pb}$ isotopic system due to superimposed tectonic and metamorphic events.

From the geotectonic standpoint, the geological, geochemical, and isotopic (U-Pb) data obtained for the CPG suggest that the investigated intrusion was generated in a convergent tectonic setting that is typical of a continental magmatic arc during an orogenic collapse, as indicated by the slight records of penetrative deformation, the younger age compared with the other granitoids of the Alumiador Intrusive Suite, and finally, the geochemical signature; for example, the $\mathrm{Rb} / \mathrm{Nb}$ versus $\mathrm{Y} / \mathrm{Nb}$ diagram of Eby (1992) indicates that the CPG samples coincide with the field of post-orogenic, A2-type granites.

The GCP participated in a plutonic-volcanic igneous event that affected the southern end of the Amazonian Craton during the Statherian, and to 
date, there is no evidence of magmatism correlated to the Paragua, Jauru, and Rio Alegre Terranes located in the SW Amazonian Craton.

The Ar-Ar and K-Ar ages of approximately $1.3 \mathrm{Ga}$ (Cordani et al. 2010), which were obtained for the rocks from the Alumiador Intrusive Suite and its host rocks, suggest that a tectonic-metamorphic episode that was correlated with the San Ignácio Orogeny (identified in the Paraguá Terrane) affected the Cerro Porã Batholith.

\section{ACKNOWLEDGMENTS}

The authors thank the Brazilian National Agency for the Support and Evaluation of Graduate Education
(Coordenação de Aperfeiçoamento de Pessoal de Nível Superior - CAPES), National Program of Academic Cooperation (Programa Nacional de Cooperação Acadêmica - PROCAD; process 096/2007) and Mato Grosso State Research Support Foundation (Fundação de Amparo à Pesquisa do Estado do Mato Grosso FAPEMAT) (Process \#448287/2009) for the financial support; and to National Institute of Science and Geosciences Technology of the Amazonian (Instituto Nacional de Ciências e Tecnologia de Geociências da Amazônia GEOCIAM) for the research support and the concession of a master's scholarship to the first author. The authors also thank the Graduate Program in Geosciences of the UFMT and the Crustal and Tectonic Evolution Research Group (Guaporé) for the financial and logistical support.

\section{REFERENCES}

Almeida F.F.M. 1967. Origem e evolução da plataforma brasileira. Rio de Janeiro, Boletim da Divisão de Geologia e Mineralogia, Boletim 241, p. 1-36

Amaral G. 1974. Geologia Pré Cambriana da Região Amazônica. Tese (doutorado). Instituto de Geociências, Universidade de São Paulo, $212 \mathrm{p}$.

Araújo H.J.T., Santos Neto A., Trindade C.A.H., Pinto J.C.A., Montalvão R.M.G., Dourado T.D.C., Palmeira R.C.B. \& Tassinari C.C.G. 1982. Folha SF. 21 - Campo Grande. Rio de Janeiro, Ministério das Minas e Energia-Secretaria Geral, Projeto RADAMBRASIL - Geologia, 28:23-124

Bettencourt J.S., Leite Jr., W.B., Ruiz A.S., Matos R., Payolla B.L. \& Tosdal R.M. 2010. The Rondonian-San Ignacio Province in the SW Amazonian Craton: An Overview. Journal of South American Earth Sciences, 29:28-46.

Cordani U.G., Tassinari C.C.G., Teixeira W., Basei M.A.S. \& Kawasita K. 1979. Evolução Tectônica da Amazônia com base nos dados geocronológicos. In: Congresso Geológico Chileno, 2, Chile. Atas, p. 137-148.

Cordani U.G. \& Brito Neves B.B. 1982. The geologic evolution of South América during the Archean and Early Proterozoic. Revista Brasileira de Geociência, 12:78-88.

Cordani U.G. \& Teixeira W. 2007. Proterozoic accretionary belts in the Amazonian Craton. In: Hatcher R.D., Carlson Jr. M.P., McBride J.H. \& Martinez Catalán J.R. (eds.). 4-D Framework of Continental Crust, vol. 200. Geological Society of America, Memoirs, p. 297-320.

Cordani U.G., Teixeira W., Tassinari C.C.G. \& Ruiz A.S. 2010. The Rio ApaCraton in Mato Grosso do Sul (Brazil) and Northern Paraguay: geochronological evolution, correlations and tectonic implications for Rodinia and Gondwana. American Journal of Science, 310:1-43.

Corrêa J.A., Corrêa Filho F.C.L, Scislewski G., Cavallon L.A., Cerqueira N.L.S. \& Nogueira V.L. 1976. Projeto Bodoquena - Relatório Final, MME/DNPM, Convênio DNPM/CPRM, Superintendência Regional de Goiânia.
Correia Filho F.C.L, Martins E.G. \& Araújo E.S. 1981. Projeto Rio Apa: Relatório da área I. Goiânia: CPRM, Convênio CODESUL/CPRM, v. 2.

Eby G.N. 1992. Chemical subdivision of the A-type granitoids: petrogenetic and tectonic implications. Geology, 20:641-644.

Godoi H.O., Martins E.G., Mello C.R. \& Scislewski G. 1999. Geologia. MME/SG. Programa levantamentos Geológicos Básicos do Brasil. Folhas Corumbá (SE.21-Y-D), Aldeia Tomázia, (SF.21-V-B) e Porto Murtinho (SF.21-V-D), Mato Grosso do Sul, escala 1:250.000.

Godoy A.M., Ruiz A.S., Manzano J.C., Araújo L.M.B. \& Ruiz A.S. 2007. Contexto geológico do magmatismo do Grupo Amoguijá, Suíte Intrusiva Alumiador e Vulcânica Serra da Bocaina, Maciço Rio Apa, sul do Cráton Amazônico MS. In: Simpósio Nacional de Estudos Tectônicos, 11, Atas, p. 277-279

Godoy A.M., Manzano, J.C., Araújo L.M.B. \& Silva J.A. 2009. Contexto Geológico e Estrutural do Maciço Rio Apa, sul do Cráton Amazônico - MS. Revista Brasileira de Geociência, 28:485-499.

Harris N.B.W., Pearce J.A. \& Tindle A.G. 1986. Geochemical characteristics of collision-zone magmatism. Special Publications of Geological Society, London, 19:67-81.

Irvine I.N. \& Baragar W.R.A. 1971. A guide to the chemical classification of the common volcanics rocks. Canadian Journal Earth Science, 8:523-548.

Lacerda Filho J.W., Brito R.S.C., Silva M.G., Oliveira C.C. De Moreton L.C., Martins E.G., Lopes R.C., Lima T.M., Larizzatti J.H. \& Valente C.R. 2006. Geologia e Recursos Minerais do Estado de Mato Grosso do Sul. Programa integração, atualização e difusão de dados de geologia do Brasil. Convênio CPRM/SICME - MS, MME, p. 10-28.

La Roche H. 1980. Granites chemistry through multicationic diagrams. Sciences de la Terre, Série Informatique Géologique, 13:65-88.

Le Bas M.J., Le Maitre R.W., Streckeisen A. \& Zanettin B.A. 1986. Chemical classification of volcanic rocks based on total alkali-silica diagram. Journal of Petrology, 27:745-750.

Le Maitre R.W. 2002. Igneous rocks: a classification and glossary of terms: recommendations of the international union of geological sciences subcommission on the systematics of igneous rocks. Cambridge, Cambridge University Press, 236 p. 
Lisboa M.A.R. 1909. Oeste de São Paulo, sul de Mato Grosso, geologia, indústria mineral, clima, vegetação, solo agrícola, indústria pastoril, Rio de Janeiro, Typ do Jornal do Commercio, 172 p.

Ludwig K.R. 1998. Isoplot/Ex. (v. 1.00b): a geochronological toolkit for Microsoft excel. Berkeley, Geochronology Center. 45 p. (Special Publication 1).

Maniar P.D. \& Piccoli P.M. 1989.Tectonic discrimination of granitoids. Geological Society American Bulletin, 101:635-643.

Nogueira V.L., Oliveira C.C., Figueiredo J.A., Corrêa Filho F.C.L., Scislewski N.G., Souza M.R., Moraes Filho J.C.R., Leite E.A., Souza N.B., Souza J.O., Cerqueira N.L.S., Vanderlei A.A., Takaschi A.T., Abreu Filho W., Rosito J., Olivatt I.O., Hausen J.E.P., Gonçalves G.N.D., Ramalho R. \& Pereira L.C.B. 1978. Projeto Bonito - Aquidauana: Relatório Final. Goiânia. Convênio: DNPM/CPRM - DGM, v. 14.

Oliveira A.J. \& Moura P. 1944. Geologia da região de Corumbá e minérios de manganês e ferro de Urucum, Mato Grosso. Boletim da Divisão de Fomento da Produção Mineral, Rio de Janeiro, parte I, 62:13-29.

Paces J.B. \& Miller Jr, J.D. 1993. Precise U-Pb ages of Duluth Complex and related mafic intrusions, northeastern Minnesota: Geochronological insights to physical, petrogenetic, paleomagnetic, and tectonomagmatic processes associated with the 1.1 Ga midcontinent rift system. Journal Geophysical Research, 98:13997-14013.

Peacock M.A. 1931. Classification of igneous rock series. Journal of Geology, 39:54-67.

Pearce J.A., Harris N.B.W. \& Tindle A.G. 1984. Trace element discrimination diagrams for the tectonic interpretation of granitic rocks. Journal of Petrology, 25(4):956-983.

Pearce J.A. 1996. Sources and settings of granitic rocks. Episodes, 19:120-125.

Ruiz A.S. 2005. Evolução geológica do sudoeste do Cráton Amazônico região limítrofe Brasil-Bolívia - Mato Grosso. Tese (doutorado). Instituto de Geociências e Ciências Exatas, Universidade Estadual Paulista, p. 14-245.

Sato K., Basei M.A.S. \& Siga O.J. 2008. Novas técnicas aplicadas ao método U-Pb no CPGeo - IGc/USP: avanços na digestão química, espectrometria de massa (TIMS) e exemplos de aplicação integrada com SHRIMP. Geologia USP - Série Científica, 8:77-99.

Santos J.O.S., Hartmann L.A., Gaudette H.E., Groves D.I., Mcnaughton N.J. \& Fletcher I.R. 2000. A new understanding of the Amazon Craton Provinces based on integration of field mapping and $\mathrm{U}-\mathrm{Pb}$ and $\mathrm{Sm}-\mathrm{Nd}$ Geochronology. Gondwana Research, 3:453-488.
Santos J.O.S., Rizzotto G.J., Potter P.E., Mcnaughton N.J., Matos R.S., Hartmann L.A., Chemale Jr. F. \& Quadros M.E.S. 2008. Age and Autochthonous Evolution of The Sunsás Orogen in the West Amazon Craton based on mapping and U-Pb Greochronology. Precambrian Research, 165:120-152.

Schobbenhaus Filho C. \& Soares L.A. 1979. Carta geológica do Brasil ao milionésimo. Folha Corumbá (SE.21). Brasília: DNPM.

Sibson R.H. 1977. Fault rocks and fault mechanisms. Journal of the Geological Society, 133:191-213.

Steiger R.H. \& Jäger E. 1977. Subcommission on geochronology: convention on the use of decay constants in geo and chosmo chronology. Earth Planetary Science Letters, 36:359-362.

Stern R.A. 1998. High resolution SIMS determination of radiogenic trace isotope ratios in minerals. In: Cabri L.J. \& Vaughan D.J. 1998. Modern approaches to ore and environmental mineralogy. Canada Short Course Series, Mineralogical Association of Canada, 27:241-268.

Sun S.S. \& McDonough W.F. 1989. Chemical and isotopic systematics of oceanic basalts: implications for mantle composition and process. In: Saunders A.D. \& Norry M.J. (Eds.), Magmatism in the Ocean Basins. Geological Society Special Publication, 42:313-345,

Tassinari C.C.G. 1996. O mapa geocronológico do Cráton Amazônico no Brasil: revisão dos dados isotópicos. Tese de Livre-Docência, Instituto de Geociências, Universidade de São Paulo, 139 p.

Tassinari C.C.G. \& Macambira M.J.B. 1999. Geochronological provinces of the Amazonian Craton. Episodes, 38:174-182.

Taylor S.R. \& McLennan S.M. 1985. The continental crust: its compositional and evolution. Black Well, Oxford, 312 p.

Teixeira W., Tassinari C.C.G., Cordani U.G. \& Kawashita K. 1989. A review of the geochronoloy of the Amazonian Craton: tectonic implications. Precambrian Research, 42:213-227.

Whalen J.B., Currie K.L. \& Chappell B.W. 1987. A-type granites geochemical characteristics, discrimination and petrogenesis. Contributions to Mineralogy and Petrology, 95(4):407-419.

Williams I. 1998. U-Th-Pb geochronology by ion microprobe, In: McKibben M.A., Shanks III W.C. \& Ridley W.I. (eds), Applications of microanalytical techniques to understanding mineralizing processes. Reviews in Economic Geology, 7:1-35.

Whright J.B. 1969. A simple alkalinity ratio and its application to questions of nonorogenic granite genesis. Geological Magazine, 106:370-389.

Winchester J.A. \& Floyd P.A. 1977. Geochemical discrimination of different magma series and their differentiation products using immobile elements. Chemical Geology, 20:325-343.

Arquivo digital disponível on-line no site www.sbgeo.org.br 